\title{
Spillover Effects of Analyst Coverage on IPO Firms*
}

\author{
Jin Q Jeon ${ }^{* *}$, Professor, Dongguk Business School
}

\begin{abstract}
$\langle$ Abstract $\rangle$
This study investigates the effect of analysts' recommendations and earnings forecasts for newly listed firms in the same industry. IPO underpricing is significantly lower as the number of firms whose investment recommendations are upgraded increases, supporting the contagion effect hypothesis that a high affinity for the industry has a positive effect on the IPO offer price. However, as the number of listed firms with higher earnings forecasts increases, IPO underpricing is higher, which supports the competitive effect hypothesis that the profit growth of competitors negatively affects IPO firms' competitiveness. The effects vary depending on the competitive positions of both listed firms and IPO firms within the industry. The results also show that in industries with high concentration (i.e. low competition), analyst information on listed firms has a greater contagion effect, while the competition effect hypothesis that better earnings forecasts for rival firms negatively affect IPO firms' competitive position is not supported. This study contributes to the literature by analyzing the information spillover effect of analyst coverage in the IPO market by showing that the effects vary depending on the firms' competitive positions as well as industry competition.
\end{abstract}

Keywords: Analyst Recommendation; Earing Forecast; Competitive Effect; Contagion Effect; IPO

JEL Classification: G24, G30

\footnotetext{
* This research was supported by Research Grant Program from the Korean Securities Association and FnGuide in 2020.

** Corresponding Author. Address: Dongguk University, 30, Pildong-ro 1-gil, Jung-gu, Seoul, Korea, 04620; E-mail: jjeon@dongguk.edu; Tel: +82-2-2260-8911, Fax: +82-2-2260-3042.
}

Received: February 15, 2021; Revised: April 26, 2021; Accepted: May 11, 2021 


\title{
경쟁기업에 대한 애널리스트 투자정보가 신규 상장기업에 미치는 영향
}

전 진 규 (동국대학교 교수)***

\begin{abstract}
본 연구에서는 업종 내 기존 상장기업에 대한 애널리스트 투자정보가 신규 상장기업의 저가발행에 미치는 영향을 2006년부터 2019년 까지 총 740건의 IPOs를 대상으로 분석하였다. 먼저 특정 업종 내 기존 상장기업에 대한 투자의견 상향 비율이 높을수록 IPO 저가발행률이 유의적으로 낮게 나타났는데, 이는 업종에 대한 높은 호감이 신규 상장기업의 공모가에도 긍정적 영향을 미친다는 전염효과 가설을 지지하는 결과이다. 반면, 기존 상장기업에 대한 이익예측치의 상향 비율이 높을수록 저가평가율이 높게 나타났는데, 이는 경쟁기업들의 이익 성장이 신규 상장기업의 업종 내 미래 경쟁력에 부정적인 영향을 미친다는 경쟁효과 가설을 지지한다. 이와 같은 효과는 IPO 기업과 경쟁기업들의 업종 내 경쟁적지위에 따라 다르게 나타났다. 업종 경쟁도를 고려하여 분석한 결과, 집중도가 높은 업종에서 기존 상장기업에 대한 투자의견 상향 정보는 전염효과가 높아 IPO 저가발행을 감소시키는 것으로 나타났다. 기존 연구들이 애널리스트 투자정보와 해당 기업의 투자성과를 분석했던 것과 달리, 본고에서는 IPO 시장을 대상으로 경쟁기업에 대한 애널리스트 투자정보의 확산효과를 최초로 분석하였다는데 의의가 있다.
\end{abstract}

핵심 단어 : 애널리스트 투자의견, 애널리스트 이익예측, 전염효과, 경쟁효과, IPO 저가평가 JEL 분류기호: G24, G30

* 본 연구는 2020년 한국증권학회-FnGuide 연구지원사업으로 수행되었으며, FnGuide 자료를 사용하였습니다.

** 연락담당 저자. 주소: 서울특별시 중구 필동로 1 길 30 동국대학교 경영대학, 04620;

E-mail: jjeon@dongguk.edu; Tel: 02-2260-8911; Fax: 02-2260-3042. 


\section{1. 서론}

본 논문은 업종 내 기존 상장기업에 대한 애널리스트 투자정보가 신규 상장기업의 가격에 미치는 영향을 검증하였다. 기존 연구들이 애널리스트 투자정보와 대상 기업의 투자성과를 분석했던 것과 달리, 본고에서는 경쟁기업에 대한 애널리스트 투자정보의 확산효과(spillover effect)를 IPO 시장을 대상으로 분석하였다.

애널리스트 투자정보는 해당 기업의 투자자, 경영쟁 등 이해관계자들의 의사결정에 큰 영향을 줄 수 있는 정보이며, 투자자의 투자수익률 뿐만 아니라 기업의 자금조달비용에도 직접적인 영향을 미친다. 이제까지 애널리스트 보고서에 관한 대부분의 연구들은 애널리스트 투자의견 혹은 이익예측치의 상향은 주가에 긍정적인 영향을, 투자의견 및 이익예측치의 하향은 주가에 부정적인 영향을 미치는 것으로 보고하였다(Jegadeesh et al., 2004; Asquith et al., 2005; Kang et al., 2007 등). Asquith et al.(2005)은 all star analysts의 예측치 정보가 투자자들의 의사결정에 직접적으로 반영된다고 하였고, Jegadeesh et al.(2004)은 애널리스트의 투자등급에 대한 컨센서스와 매수와 매도추천 정보를 이용하여 투자할 경우 벤치마크 대비 정(+)의 초과수익을 얻을 수 있다고 하였다. Kang et al.(2007)은 애널리스트의 투자등급 컨센서스 변경 효과가 유의하게 존재하며, 특히 가치주에서 그 유용성이 높다고 보고하였다. 또한 투자의견 변경에 의한 가격조정은 투자의견 상향.하향 여부, 시장상황 및 기업의 특성에 따라 즉각적으로 일어나기도 하고 시간을 두고 지연반응 현상이 나타나기도 한다(Hirshleifer and Teoh, 2003; Ha et al., 2019 등).

한편 애널리스트 투자정보는 확산효과를 가진다. Israelsen(2016)은 동일한 애널리스트에 의해 분석된 주식들의 수익률 상관관계가 높다고 하였고, Hameed et al.(2015)은 업종 내 우월적 지위를 가진 기업에 대한 투자의견은 업종 내 다른 기업들의 주가에 영향을 미친다고 하였다. 따라서 특정기업에 대한 투자의견 변경은 해당기업의 투자자, 경영진을 포함한 이해관계자에 직접적인 영향을 미칠 뿐만 아니라 동종 업계 내 경쟁기업의 주가에도 영향을 미칠 수 있어, 경쟁기업의 투자자, 경영진 등 이해관계자들의 주요 관심사가 된다.

그럼에도 불구하고 아직까지 국내 학계에서는 애널리스트 투자정보가 경쟁기업의 주가에 어떠한 영향을 미치는 지에 대한 연구가 미미한 실정이다. 그 이유 중 하나는 자료의 구성이 복잡하고 실증분석 시 투자정보와 주가 간 동시성 문제(simiultaneity)등으로 인한 내생성문제가 존재하며 투자정보가 영향을 미치는 경로 및 기간 등이 불명확하여 변수들 간 관계를 검증하기가 매우 어렵기 때문이다. 이에 본 연구에서는 IPO 시장에 업종 내 기업들에 대한 투자정보 및 이익예측치 변경이 신규 상장기업의 가격에 미치는 영향에 대하여 분석함으로서 애널리스트 투자정보의 확산효과를 검증하고자 하였다. IPO 기업의 관점에서 업종 내 경쟁기업들에 대한 투자정보 등의 변경은 외생적으로 결정되므로 동시성 문제가 존재하지 않으며, 경로 및 기간의 문제도 비교적 명확하게 측정할 수 있는 장점이 있다.

애널리스트의 개별종목 분석에는 업종분석을 담당하는 섹터 애널리스트와 경제상황을 분석 하는 매크로 애널리스트들의 의견이 적극적 반영된다. 이는 개별기업의 가치평가에 있어서 
경제분석 뿐만 아니라 해당 업종의 전망에 대한 분석은 필수적이기 때문이며, 특별한 경우를 제외하면 대부분의 개별주식 주가는 이들 분석결과에 지대한 영향을 받는다. 따라서 특정 기업에 대한 투자의견 또는 이익예측치의 상향(또는 하향) 변경은 동일 업종 내 경쟁기업의 주가에도 긍정적(또는 부정적) 영향을 미친다. 이와 같이 특정기업이 속한 업종 또는 업종 내 경쟁기업에 대한 호의적인 의견이 해당 기업에도 긍정적인 영향을 미치는 상황을 본 연구에서는 이를 전염효과(contagion effect)가설이라고 한다. 전염효과가설에 의하면 업종 내 기존 상장기업에 대한 투자의견 또는 이익예측치의 상향(또는 하향)은 신규 상장기업의 공모가에 긍정적(또는 부정적) 영향을 미쳐 저가평가율을 감소(또는 확대) 시킴을 의미한다.

그러나 다른 한편으로는 업종 내 경쟁기업 대한 호의적 평가가 특정 기업의 가치에 부정적인 영향을 미칠 수도 있거나 긍정적인 영향을 미치지 않을 수 있다. 예를 들면, 업종 내 경쟁관계에 있는 기업들에 대한 투자의견 또는 이익예측치가 상향된다는 것은 특정기업의 미래 시장점유율이 감소하며 업종 내 경쟁적 지위가 위태로워질 수 있음을 의미할 수 있다. 기업 간 경쟁관계가 보완적이기 보다는 대체적 경쟁관계일 경우 이러한 현상은 더욱 강하게 나타날 것이다. 본고에서는 이를 경쟁효과(competitive effect)가설이라고 한다. 나아가 기업의 특성이 매우 이질적이라면 업종 내 경쟁기업들에 대한 투자의견 변경에 대한 영향을 받지 않을 수 있으며, 해당 섹터에 대한 포트폴리오의 전략적 비중이 고려될 경우 업종 내 투자 의견 변경에 대한 영향은 이질적으로 작용될 수 있다. 더불어 주가는 펀더멘털 뿐만 아니라 특정 기업 주식에 대한 수급상황에도 영향을 받는다는 점에서, 기업에 대한 수급 고유의 원인에 따라 주가가 결정될 수도 있다. 요컨대 경쟁효과 가설에 의하면 포트폴리오 전략적 비중 및 수급적 요인에 따른 업종 내 경쟁기업들에 대한 투자의견 상향(또는 하향) 조정은 신규 상장기업의 공모가에 영향을 미치지 않거나 오히려 부정적(또는 긍정적) 영향을 미칠 수 있다.

이와 같은 논의를 바탕으로 본 연구에서는 애널리스트의 투자의견과 예측이익의 전염효과와 경쟁효과를 기업공개시장을 대상으로 검증하였다. 2006년부터 2019년 까지 총 740건의 IPO를 대상으로 분석한 결과 $\mathrm{IPO}$ 공모가 대비 첫날수익률(또는 상장 후 5 일 동안 수익률) 평균은 $\mathrm{KOSPI}$ 시장에서 27.8\%(또는 27.1\%), KOSDAQ시장에서 34.9\%(또는 30.1\%)를 보였다. 회귀분석 결과, 먼저 업종 내 기존 상장기업에 대한 애널리스트 추천의견 및 이익예측 커버리지가 많을수록 통계적으로 유의하게 낮은 저가발행률을 보였다. 애널리스트 커버리지는 해당업종에 대한 시장의 관심을 반영하며 정보의 불균형을 해소하는 역할을 수행하기 때문으로 해석될 수 있다. 한편 기존 상장기업에 대한 투자의견 상향 비율이 높을수록 저가발행률이 유의적으로 낮게 나타났는데, 이는 업종에 대한 높은 호감이 신규 상장기업의 공모가에도 긍정적 영향을 미친다는 전염효과 가설을 지지한다. 반면, 기존 상장기업에 대한 이익예측치의 상향 비율이 높을수록 저가평가율이 높게 나타났다. 이는 경쟁기업들의 이익 성장이 신규 상장기업의 업종 내 경쟁력에 부정적인 영향을 미치기 때문이며, 경쟁효과 가설을 지지한다. 이와 같이 애널리스트의 투자의견과 이익예측은 신규 상장기업에 이질적인 영향을 미치는 것으로 나타났다. 
한국증권학회지 제 50 권 5 호 (2021)

업종 내 경쟁적 지위를 고려한 회귀분석 결과, 매출액 기준 상위 $25 \%$ 에 속하는 IPO 기업의 경우 자신과 비슷한 경쟁적 지위에 있는 기존 상장기업들에 대한 투자의견과 이익예측치에 유의한 영향을 받으나, 경쟁적 지위가 상대적으로 낮은 하위 $75 \%$ 기업들에 대한 투자의견과 이익예측치에는 유의한 영향을 받지 않는다. 반면, 매출액 기준 하위 $25 \%$ 에 속하는 IPO 기업은 동 그룹 내 기존 상장기업들 뿐만 아니라 상대적으로 경쟁적 지위가 우월한 상위 $75 \%$ 기업들에 대한 투자의견과 이익예측치에 유의한 영향을 받는 것으로 나타났다. 업종 경쟁도를 고려하여 분석한 결과, 집중도가 높은(또는 경쟁도가 낮은) 업종에서 기존 상장기업에 대한 투자의견 상향 정보는 전염효과가 높아 IPO 저가발행을 감소시키는 것으로 나타났다. 반면, 이러한 업종에서는 경쟁기업에 대한 이익예측치가 상향되더라도 IPO 기업의 경쟁적 지위에 유의한 영향을 미치지 않으므로 저가발행에 유의한 영향을 미치지 않았다.

본 연구는 최초로 업종 내 기존 상장기업에 대한 애널리스트 투자정보가 신규 IPO 기업의 공모가에 미치는 영향을 분석하였다는데 의의가 있다. 또한 기존 상장기업에 대한 애널리스트 투자의견 상향은 IPO 기업의 공모가에 긍정적인 영향을 미치는 전염효과가 관찰된 반면, 기존 상장기업에 대한 이익예측치 상향은 $\mathrm{IPO}$ 기업의 업종 내 경쟁적 지위에 부정적인 영향을 미치는 경쟁효과가 있음을 보고하였다. 즉, 애널리스트 투자정보 중 투자의견과 이익예측치가 경쟁기업에 이질적인 영향을 미친다는 결과도 시사점이 크다고 할 수 있다. 마지막으로 경쟁효과 또는 전염효과는 기업의 업종 내 경쟁적 지위에 따라 또는 업종 경쟁도에 따라 다르게 나타남을 보였다는 점도 주목할 부분이다.

본 논문의 구성은 다음과 같다. 제 2장에서는 선행연구를 검토하고 연구가설을 설정하였다. 제 3장에서는 연구표본 및 연구방법론을 기술하였고, 제 4장에서 실증분석 결과를 제시하였다. 제 4장에서는 결론 및 시사점을 제시하였다.

\section{2. 선행연구 검토 및 연구가설 설정}

애널리스트 투자의견 변경이 동일 섹터 내 상장 중 기업의 주가에 미치는 영향이라는 주제와 관련하여 두 가지 가설이 가능하다. 첫 번째 가설로 섹터 내 투자의견 변경은 업종 장래 전망과 업종 내 기업들의 미래 현금흐름에 대한 정보를 제공하게 되므로, 투자의견 상향의 발생은 경쟁기업의 투자수요에 긍정적 영향을 미쳐 주가가 상승하게 된다. 반면에 투자의견 하향의 발생은 업종의 전망에 대하여 부정적인 정보를 제공하므로 경쟁기업의 투자수요에도 부정적인 효과가 발생할 수 있다. Israelsen(2016)은 동일한 애널리스트에 의해 분석된 주식들의 수익률 상관관계가 높다고 하였고, Hameed et al.(2015)은 업종 내 우월적 지위를 가진 기업에 대한 투자의견은 업종 내 다른 기업들의 주가에 영향을 미친다고 하여 위의 가설과 일치한다.

금융시장에서 위와 같은 정보의 확산효과는 다양하게 나타난다. Song and Walkling(2000)은 경쟁기업 기업의 피합병 공시는 기업 주가를 높인다고 하였다. 업종 내 부도 발생 시 업종전체의 주가가 떨어지는 현상(Ferris et al., 1997) 및 부도기업과 계약관계가 있는 기업의 주가가 떨어지는 현상(Hetzel et al., 2008)도 보고되었다. 같은 맥락에서 업종 내 기업들의 애널리스트 투자의견 
상향(또는 하향) 조정이 투자자에게 업종 대한 긍정적(혹은 부정적) 신호를 전달한다면, 신규 상장기업의 가치에도 그에 상응한 영향을 미칠 것이다. 이상의 가설을 '전염효과(contagion effect) 가설'이라고 부르고자 하며, 다음과 같은 세부가설을 제시한다.

가설 1-1: (전염효과 가설) 기존 상장기업에 대한 애널리스트 투자의견의 상향(또는 하향)은 신규 상장기업의 저가발행률에 부정적(또는 긍정적) 영향을 미칠 것이다.

한편, Hsu et al.(2010)은 업종 내 IPO 기업이 신규 상장된 경우 기존 상장기업의 경영성과와 재무성과가 감소한다고 보고하였다. 그 주요 이유는 업종 내 새로운 경쟁기업의 진입으로 인하여 기업 간 경쟁도가 강화되기 때문이라고 설명하였다. 같은 맥락에서 애널리스트 투자의견에서 업종 전망의 가중치가 낮고 대상 기업 전망에 대한 가중치가 높다고 인식될 경우 투자의견의 변경은 경쟁기업의 주가에 반대로 작용할 것이다. Li et al.은 중국의 기업공개시장에서 신규상장에 대한 금융당국의 승인은 업종 내 상장기업의 주가에 부정적인 영향을 미친다고 하였는데, 업종 내 기존의 수요-공급 균형을 변경시킬 것이라는 예측이 반영되었기 때문이다. Lang and $\operatorname{Stulz}(1992)$ 는 부도 발생 시 업종 내 경쟁사의 주가를 평균 $1 \%$ 하락시키지만, 집중도가 낮거나 부채비율이 낮은 업종 내 기업들에게는 오히려 경쟁도가 낮아지는 효과가 있어 긍정적인 영향을 미친다고 하였다. Chen et al.(2005)는 신상품 개발 공시가 업종 내 경쟁기업의 가치에 부정적 영향을 미친다고 했다. 위의 연구들을 토대로 다음과 같은 경쟁효과(competitive effect) 가설을 설정한다.

가설 1-2: (경쟁효과 가설) 기존 상장기업에 대한 애널리스트 투자의견의 상향(또는 하향)은 신규 상장기업의 저가발행률에 긍정적(또는 부정적) 영향을 미칠 것이다.

증권회사의 애널리스트가 제공하는 기업의 목표주가와 투자의견은 기업의 미래이익 예측에 기반한다. 애널리스트의 이익예측능력에 관한 기존연구들은 대부분 정보우위에 있는 애널리스트의 이익예측이 기업의 주가에도 유의한 영향을 미친다고 보고하고 있다(Miller, 2005; Kasznik and McNichols, 2002; Kang et al., 2007; Kim and Park, 2012 등). 따라서 위의 가설들에서 신규 상장기업의 저가발행률은 기존 상장기업에 대한 애널리스트의 투자의견 뿐만 아니라 애널리스트의 이익예측으로부터도 유의한 영향을 받을 것으로 예측되므로 다음과 같은 추가 가설을 설정한다.

가설 2-1: (전염효과 가설) 기존 상장기업에 대한 애널리스트 이익예측치의 상향(또는 하향)은 신규 상장기업의 저가발행률에 부정적(또는 긍정적) 영향을 미칠 것이다.

가설 2-2: (경쟁효과 가설) 기존 상장기업에 대한 애널리스트의 이익예측치의 상향(또는 하향)은 신규 상장기업의 저가발행률에 긍정적(또는 부정적) 영향을 미칠 것이다.

한편, 위와 같은 영향은 업종 내 기존 상장기업에 대한 신규 상장기업의 경쟁적 지위 및 
업종 내 경쟁도에 따라 다르게 나타날 것이다. 기존 상장기업 중 경쟁적 지위가 높은 기업에 대한 투자의견 또는 이익예측치 변경의 정보 확산효과가 더 클 것으로 예측된다. 그러므로 신규 상장기업의 주가는 업종 내 경쟁적 지위가 상대적으로 낮은 기업보다는 경쟁적 지위가 상대적으로 높은 기업에 대한 투자의견 및 이익예측치 변경에 더 많은 영향을 받을 것이다. 마지막으로 업종 경쟁도에 따라 신규 상장기업의 주가도 다르게 반영하는데, 예를 들면 경쟁도가 높은 업종일수록 경쟁효과가 더 크게 나타날 것이고, 경쟁도가 낮은 업종일수록 전염효과가 상대적으로 더 크게 나타날 것으로 예측된다. 이상의 논의를 토대로 다음과 같은 세부가설을 설정한다.

가설 3-1: 투자의견 변경이 발생한 상장기업의 경쟁적 지위에 따라 신규 상장기업의 저가발행률에 미치는 영향이 달라질 것이다.

가설 3-2: 신규 상장기업의 업종 내 경쟁적 지위에 따라 신규 상장기업의 저가발행률에 미치는 영향이 달라질 것이다.

가설 3-3: 기존 상장기업에 대한 애널리스트 투자의견 및 이익예측치 변경이 신규 상장기업의 저가발행률에 미치는 영향은 업종 경쟁도에 따라 다르게 나타날 것이다.

\section{3. 표본 및 연구방법론}

\section{1 연구 표본}

본 연구에서는 2006년부터 2019년 기간 동안 KOSPI 및 KOSDAQ시장에 상장한 IPO 기업 중에서 금융 업종, 재상장, 분할상장, 스펙상장 및 중국계 상장기업을 제외한 총 740 개의 신규상장기업을 대상으로 분석하였다. 공모가격 등 IPO 관련 자료는 금융감독원 전자공시시스템 (DART, http://dart.fss.or.kr/)에서 개별 추출하였으며, 공모 후 주가 및 재무관련 자료는 나이스신용평가에서 제공하는 Kis-Value와 에프앤가이드(FnGuide)에서 제공하는 DataGuide를 통해 수집하였다. 기존 상장주식에 대한 애널리스트 투자의견 및 이익예측 자료는 DataGuide를 통해 수집하였다. 애널리스트 투자의견은 5 점 척도 1 = 강력매도, 2 = 매도, 3 = 보유, $4=$ 매수, 5 = 강력매수)로 측정한다.

〈표 1〉IPO 저가발행의 연도별 분포

아래 표는 첫날수익률과 공모가 대비 상장 후 5 일 동안 수익률로 측정된 IPO 저가발행률의 연도별 분포이다.

\begin{tabular}{llccccc}
\hline \multirow{2}{*}{ Year } & & \multicolumn{2}{c}{ KOSPI } & & \multicolumn{2}{c}{ KOSDAQ } \\
\cline { 3 - 4 } \cline { 6 - 7 } & & First day returns & 5 5-day returns & & First day returns & 5-day returns \\
\hline \multirow{2}{*}{2006} & Mean & 120 & & & 620 & \\
& Median & 0.668 & 0.465 & & 0.543 & 0.374 \\
& 0.672 & 0.453 & & 0.386 & 0.181 \\
\hline
\end{tabular}


Spillover Effects of Analyst Coverage on IPO Firms

〈표 1〉IPO 저가발행의 연도별 분포(계속)

\begin{tabular}{|c|c|c|c|c|c|}
\hline \multirow{2}{*}{ Year } & & \multicolumn{2}{|c|}{ KOSPI } & \multicolumn{2}{|c|}{ KOSDAQ } \\
\hline & & First day returns & 5-day returns & First day returns & 5-day returns \\
\hline \multirow[t]{2}{*}{2007} & Mean & 0.424 & 0.391 & 0.349 & 0.187 \\
\hline & Median & 0.268 & 0.197 & 0.148 & 0.009 \\
\hline \multirow[t]{2}{*}{2008} & Mean & -0.081 & -0.137 & 0.177 & 0.099 \\
\hline & Median & -0.091 & -0.146 & 0.116 & 0.037 \\
\hline \multirow[t]{2}{*}{2009} & Mean & 0.268 & 0.232 & 0.533 & 0.510 \\
\hline & Median & 0.229 & 0.280 & 0.320 & 0.166 \\
\hline \multirow[t]{2}{*}{2010} & Mean & 0.282 & 0.307 & 0.230 & 0.255 \\
\hline & Median & 0.163 & 0.189 & 0.129 & 0.102 \\
\hline \multirow[t]{2}{*}{2011} & Mean & 0.271 & 0.347 & 0.317 & 0.227 \\
\hline & Median & 0.182 & 0.188 & 0.222 & 0.047 \\
\hline \multirow[t]{2}{*}{2012} & Mean & 0.032 & -0.030 & 0.334 & 0.433 \\
\hline & Median & -0.042 & -0.058 & 0.240 & 0.150 \\
\hline \multirow[t]{2}{*}{2013} & Mean & 0.459 & 0.422 & 0.354 & 0.342 \\
\hline & Median & 0.454 & 0.450 & 0.190 & 0.074 \\
\hline \multirow[t]{2}{*}{2014} & Mean & 0.509 & 0.673 & 0.353 & 0.404 \\
\hline & Median & 0.535 & 1.095 & 0.388 & 0.318 \\
\hline \multirow[t]{2}{*}{2015} & Mean & 0.225 & 0.302 & 0.389 & 0.409 \\
\hline & Median & 0.012 & 0.044 & 0.289 & 0.260 \\
\hline \multirow[t]{2}{*}{2016} & Mean & 0.154 & 0.279 & 0.268 & 0.216 \\
\hline & Median & 0.059 & -0.015 & 0.170 & 0.113 \\
\hline \multirow[t]{2}{*}{2017} & Mean & -0.010 & -0.059 & 0.330 & 0.307 \\
\hline & Median & -0.030 & -0.057 & 0.219 & 0.216 \\
\hline \multirow[t]{2}{*}{2018} & Mean & 0.138 & 0.079 & 0.365 & 0.367 \\
\hline & Median & 0.168 & 0.000 & 0.231 & 0.135 \\
\hline \multirow[t]{2}{*}{2019} & Mean & 0.274 & 0.460 & 0.279 & 0.183 \\
\hline & Median & 0.185 & 0.199 & 0.108 & 0.107 \\
\hline \multirow[t]{2}{*}{ Total } & Mean & 0.278 & 0.271 & 0.349 & 0.301 \\
\hline & Median & 0.168 & 0.094 & 0.222 & 0.131 \\
\hline
\end{tabular}

<표 1>은 2006년부터 2019년까지 KOSPI시장에 상장된 120건의 IPO와 KOSDAQ시장에 상장된 620 건의 $\mathrm{IPO}$ 에 대한 저가발행률에 대한 연도별 평균 및 중앙값을 보여준다. 저가발행률은 공모가 대비 첫날종가수익률과 공모가 대비 상장 후 5일 동안 수익률을 사용하였다. KOSPI시장 및 $\mathrm{KOSDAQ}$ 시장에 $\mathrm{IPO}$ 의 첫날수익률(또는 상장 후 5일간 수익률) 평균은 각각 $27.8 \%$ (또는 $27.1 \%$ ) 및 34.9\%(또는 30.1\%)이었다. $\mathrm{KOSDAQ}$ 시장에서 높게 나타났다.

<표 2>는 KOSPI시장과 $\mathrm{KOSDAQ}$ 시장의 업종 구분을 사용하여 IPO 저가발행률의 분포를 보여준다. KOSPI시장에서는 유통업과 의료정밀 업종의 저가발행률이, KOSDAQ시장에서는 금속과 소프트웨어 업종의 저가발행률이 상대적으로 높게 나타났다. 
한국증권학회지 제 50 권 5 호 (2021)

〈표 2〉업종별 IPO 저가발행률 분포

아래 표는 IPO 저가발행률의 업종별 분포이다.

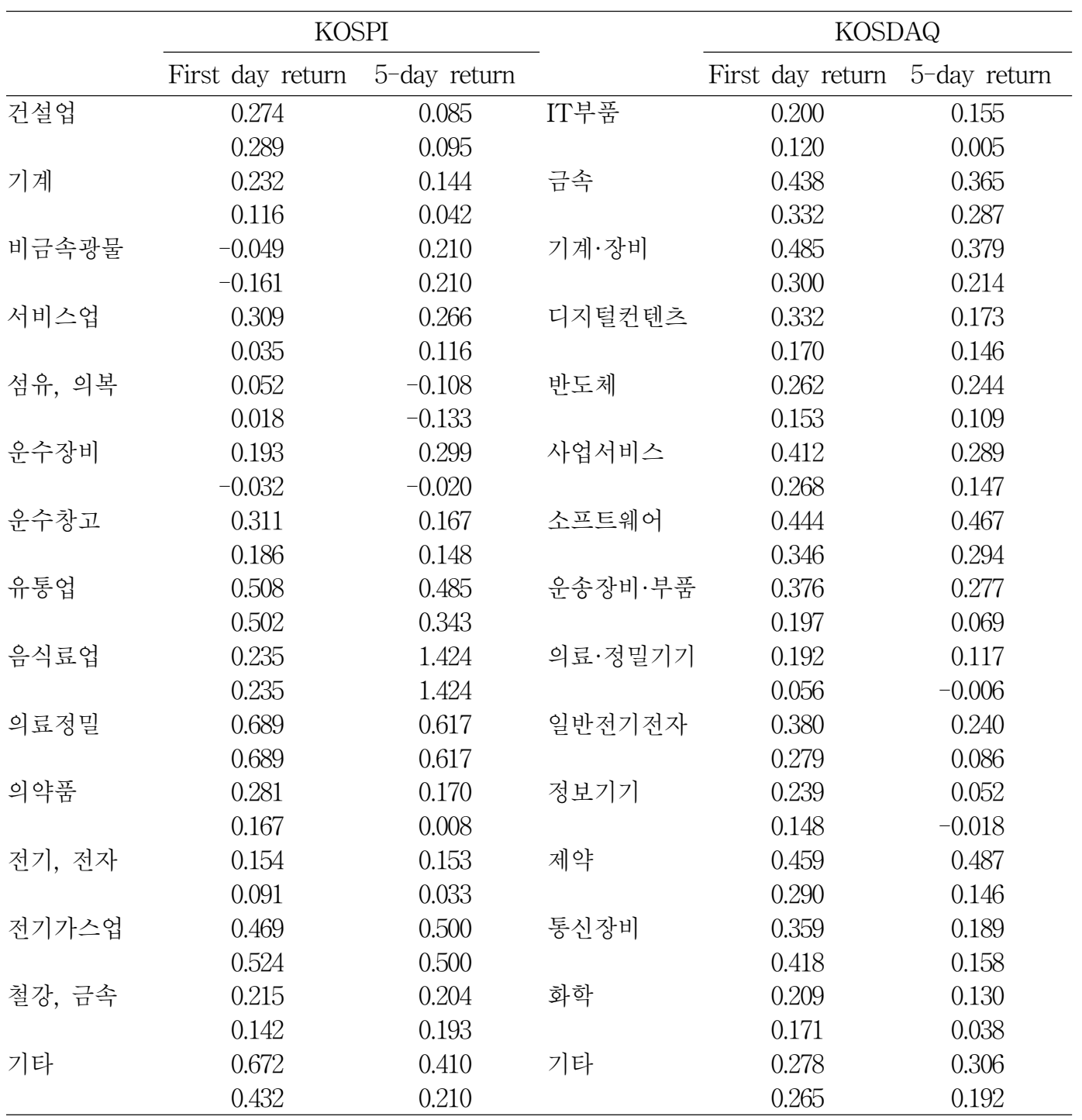

\section{2 연구방법론}

상장기업에 대한 애널리스트 투자의견 및 예측 순이익이 신규 상장기업의 저가발행률에 미치는 영향을 분석하기 위하여 다음과 같은 회귀식을 추정한다.

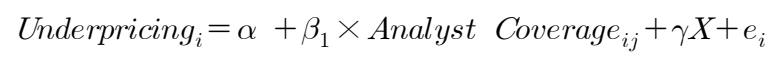

식 (1)에서 사용된 주요 변수들에 대한 정의는 다음과 같다. 저가발행률(Underpricing)로 
IPO 첫날수익률(First day return)과 상장 후 5일간 수익률(5-day return)을 사용하였다. 첫날수익률(First-day return)은 공모가 대비 첫 거래일 종가 수익률 $\left(=\ln \left(\frac{P_{1}}{\text { offerprice }}\right)\right)$ 이다. 또한 국내 시장에서 가격제한폭 제한이 있다는 점을 고려하여 공모가 대비 제 5 영업일 종가 수익률인 5-day return을 사용하였다.1)

애널리스트의 투자의견 및 예측순이익 관련변수(Analyst Coverage)로 업종 내 상장기업들에 대한 애널리스트 보고서 발행 비율(\%Anal Coverage, \%Earning Coverage), 투자의견 또는 예측순이익 상향(\%Rating Up, \%Earning UP) 또는 하향(\%Rating Down, \%Earning Down), 그리고 상향비율과 하향비율 간 차이(\%Rating Net, \%Earning Net)등을 사용하였다.2) 먼저 $\%$ Anal Coverage는 IPO 직전 3개월 동안 투자의견을 제시한 애널리스트가 하나 이상 존재하는 기업의 수를 업종 내 모든 상장기업의 수로 나눈 값이다. \%Rating Up(또는 \%Rating Down)은 $\mathrm{IPO}$ 직전 3개월 동안 발표된 투자의견이 직전 6개월 동안의 투자의견보다 높은(또는 낮은) 애널리스트가 하나이상 존재하는 기업의 수를 업종 내 모든 상장기업의 수로 나눈 값이다. \%Rating Net은 \%Rating Up에서 \%Rating Down을 차감한 값이다. \%Earning Coverage는 $\mathrm{IPO}$ 직전 3 개월 동안 기존 상장기업 중 1 건 이상 애널리스트 예측순이익 자료가 있는 기업 수를 업종 내 모든 상장기업의 수로 나눈 값이다. \%Earning UP(또는 \%Earning Down) 은 $\mathrm{IPO}$ 직전 3 개월 동안 발표된 증권사별 순이익추정치의 평균값의 12 개월 trailing 순이익에 대한 12 개월 forward 순이익의 증가율 $(=(12$ 개월 forward 순이익 $) /(12$ 개월 trailing 순이익) -1)이 1 이상(또는 1 이하)인 기업의 수를 업종 내 모든 상장기업의 수로 나눈 값이다. 마지막으로 \%Earning Net은 \%Earning UP에서 \%Earning Down을 차감한 값이다.

$\mathrm{X}$ 는 통제변수의 집합으로 $\mathrm{Ln}$ (proceeds)는 공모규모의 자연로그 값이다.3) Firm Age는 기업 연혁으로 창립일 부터 해당 년까지의 기간에 대한 자연로그 값이다. Underwriter Prestige는 주관사의 명성을 나타내는 변수로, 해당 주관사가 매년 인수업무 수주기준 상위 5 위 이내일 경우 1 의 값을 갖는 더미변수이다. ROA는 당기순이익을 총자산으로 나눈 값이며, Debt ratio는 총부채를 총자기자본으로 나눈 값이다. Ln(offer price)는 공모가의 자연로그 값이며, Venture backed는 기업공개 전 벤쳐캐피탈의 투자를 받은 경우 1의 값을 갖는 더미변수이다.4) Market returns는 종속변수에 따라 상장 당일 또는 상장 이후 5일 간 코스피 또는 코스닥지수의 수익률이다. 이밖에 각 회귀식에서 공모 해(year)와 업종을 통제하였다.

1) 국내 증권시장은 상 $(+30) \cdot$ 하한가 $(-30)$ 제도, 2015 년 이전은 \pm 15 가 존재하므로 첫날수익률을 IPO 저평가률로 사용할 경우 저평가현상이 과소평가 될 가능성이 있다. 따라서, Lim et al.(2016)은 상장 후 3일 또는 5일 수익률을, Byun and Cho(2011)는 5일 또는 10일 수익률을, Song and Jeon(2019)은 상장 10 일, 20 일 및 30 일 수익률을 사용하는 등 상장 후 다양한 기간의 수익률을 저가평가율로 사용하고 있다.

2) 업종 분류는 KOSPI시장과 KOSDAQ시장에서 사용하고 있는 한국표준산업분류 기준을 따른다.

3) 통제변수 중 시가총액 또는 총자산 등 기업규모 관련 변수는 공모규모와 상관관계가 높아 다중공선성의 가능성이 있어 회귀식에서 제외하였다.

4) 우리나라는 벤처특별법 제 2 조 2 항에 적용되는 기업을 벤처기업으로 분류하고 있다. 


$$
\begin{aligned}
& \text { Underpricing }_{\text {Top } 25}=\alpha+\beta_{1} \times \text { Analyst Coverage }_{(\text {Top } 25 \text { or Bottom } 25) j}+\gamma X+e_{i} \\
& \text { Underpricing }_{\text {Bottom } 25}=\alpha+\beta_{1} \times \text { Analyst Coverage }_{(\text {Top } 25 \text { or Bottom } 25)}+\gamma X+e_{i}
\end{aligned}
$$

식 (2)에서는 신규 상장기업과 기존 상장기업의 업종 내 경쟁적 지위에 따른 저가평가율의 영향을 분석하였다. Top25(또는 Bottom25)는 매출액 기준 업종 내 상위 25\%(또는 하위 25\%) 속하는 기업을 의미한다. 식 (2)의 첫 번째 회귀식은 IPO 기업이 업종 내 상위 $25 \%$ 이내일 경우 상위 $25 \%$ 기존 상장기업 또는 하위 $25 \%$ 기존 상장기업에 대한 애널리스트 분석이 저가평가에 영향을 미치는지 검증한 식이다. 같은 방법으로 두 번째 회귀식은 IPO 기업이 하위 $25 \%$ 일 경우를 검증하였다. Analyst Coverage와 통제변수들의 정의는 위 식 (1)과 같다.

마지막으로 업종 별 집중도에 따른 경쟁효과 또는 전염효과 가설을 검증하기 위하여 업종 내 모든 상장기업들의 시장점유율을 제곱하여 합한 값인 Herfindahl-Hirschman Index(HHI) $\left(H H I=\sum_{i=1}^{N}\left(\text { Market Share }_{i}\right)^{2}\right)$ 를 사용하였다. $\mathrm{HHI}$ 값이 클수록 업종 내 집중도가 높으므로 경쟁도는 낮아진다. 일반적으로 이 지수가 2,500 이상이면 매우 집중된 시장이며, 1,500 미만이면 경쟁도가 높은 시장으로 분류된다. $\mathrm{HHI}$ 지수를 사용하여 다음과 같은 회귀식을 설정하고, 저가평가율에 대한 영향을 검증한다.

$$
\begin{aligned}
\text { Underpricing }_{i}= & \alpha+\beta_{1} \times(\text { Analyst Coverage } \cdot H H I)_{i j} \\
& +\beta_{2} \cdot \text { Analyst Coverage }_{i i}+\beta_{3} \cdot H H I_{i}+\gamma X+e_{i}
\end{aligned}
$$

\section{4. 실증분석 결과}

<표 3>은 IPO 직전 3개월 동안 업종 내 상장기업들에 대한 애널리스트 투자의견과 순이익 예측 관련 변수들의 분포를 보여준다. 각 업종 내 모든 기업들 중 투자의견(\%Anal Coverage) 또는 순이익예측(\%Earning Coverage)을 제시한 비율은 평균 $87.2 \%$ 또는 $84.87 \%$ 였다. 이중 투자의견 상향(\%Rating Up) 또는 순이익 상향 비율은 평균 $1.59 \%$ 또는 $11.89 \%$ 였으며, 하향 비율(\%Rating Down 또는 \%Earning Down)은 평균 $1.23 \%$ 또는 $10.06 \%$ 였다. 상향비율과 하향비율의 차이(\%Rating Net, \%Earning Net)는 평균 $0.37 \%$ 또는 $1.83 \%$ 였다.

〈표 3〉IPO 직전 3개월 동안 경쟁기업들에 대한 애널리스트 투자의견과 IPO 저가평가율 아래 표는 IPO 직전 3개월 동안 동일 업종 내 상장기업들에 대한 애널리스트 투자의견과 IPO 저가평가율 간 관계를 분석한 결과이다. 종속변수는 IPO 첫날수익률 및 상장 후 5 일간 수익률이다. 모든 변수들은 3.2 절에 정의되었다. 꺽쇠괄호 안의 숫자는 robust standard errors로 계산된 $\mathrm{t}$ 값 이다. 업종과 연도 더미변수들은 회귀식에 포함되었지만 회귀계수는 보고하지 않았다. * ${ }^{* *},{ }^{* * *}$ 는 각각 $10 \%, 5 \%, 1 \%$ 에서 통계적으로 유의함을 나타낸다.

\begin{tabular}{cccc}
\hline Dependent Var : & First-day Returns & 5-day Returns \\
\hline \% Anal Coverage & $-0.0471^{* *}$ & $-0.055^{*}$ & \\
& $-[2.05]$ & $-[1.97]$ & \\
\hline
\end{tabular}


Spillover Effects of Analyst Coverage on IPO Firms

〈표 3〉IPO 직전 3개월 동안 경쟁기업들에 대한 애널리스트 투자의견과 IPO 저가평가율(계속)

\begin{tabular}{|c|c|c|c|c|c|c|c|c|}
\hline \multirow{2}{*}{$\frac{\text { Dependent Var }}{\text { \% Rating Up }}$} & \multicolumn{4}{|c|}{ First-day Returns } & \multicolumn{4}{|c|}{ 5-day Returns } \\
\hline & & $\begin{array}{c}-0.1123^{* *} \\
-[1.98]\end{array}$ & & & & $\begin{array}{c}-0.0931^{*} \\
-[1.72]\end{array}$ & & \\
\hline \% Rating Down & & & $\begin{array}{l}-0.0711 \\
-[0.10]\end{array}$ & & & & $\begin{array}{r}-0.1723 \\
-[0.16]\end{array}$ & \\
\hline$\%$ Rating Net & & & & $\begin{array}{l}-0.1726 \\
-[1.49]\end{array}$ & & & & $\begin{array}{l}-0.1623 \\
-[0.33]\end{array}$ \\
\hline Ln(proceeds) & $\begin{array}{l}-0.1045^{* * *} \\
-[5.79]\end{array}$ & $\begin{array}{l}-0.112^{* * *} \\
-[6.15]\end{array}$ & $\begin{array}{l}-0.1075^{* * *} \\
-[6.03]\end{array}$ & $\begin{array}{l}-0.1153^{* * *} \\
-[6.07]\end{array}$ & $\begin{array}{l}-0.0934^{* * *} \\
-[3.84]\end{array}$ & $\begin{array}{l}-0.0965^{* * *} \\
-[4.17]\end{array}$ & $\begin{array}{l}-0.0996^{* * *} \\
-[4.25]\end{array}$ & $\begin{array}{l}-0.101^{* * *} \\
-[4.13]\end{array}$ \\
\hline Firm Age & $\begin{array}{c}-0.0300^{*} \\
-[1.97]\end{array}$ & $\begin{array}{l}-0.0401^{*} \\
-[1.73]\end{array}$ & $\begin{array}{l}-0.0505^{*} \\
-[1.95]\end{array}$ & $\begin{array}{l}-0.0443^{* *} \\
-[2.35]\end{array}$ & $\begin{array}{l}-0.0497^{*} \\
-[1.88]\end{array}$ & $\begin{array}{c}-0.0437^{*} \\
-[1.72]\end{array}$ & $\begin{array}{c}-0.0446^{*} \\
-[1.91]\end{array}$ & $\begin{array}{l}-0.0471 \\
-[1.58]\end{array}$ \\
\hline Underwriter Prestige & $\begin{array}{l}-0.0145 \\
-[0.98]\end{array}$ & $\begin{array}{l}-0.0209 \\
-[0.47]\end{array}$ & $\begin{array}{l}-0.0196 \\
-[0.44]\end{array}$ & $\begin{array}{r}-0.0109 \\
-[0.56]\end{array}$ & $\begin{array}{r}0 \\
-[1.52]\end{array}$ & $\begin{array}{r}-0.0018 \\
-[1.62]\end{array}$ & $\begin{array}{c}0.0022 \\
-[1.52]\end{array}$ & $\begin{array}{l}-0.001 \\
-[1.42]\end{array}$ \\
\hline $\mathrm{ROA}$ & $\begin{array}{r}0.0410 \\
{[0.52]}\end{array}$ & $\begin{array}{c}0.032 \\
{[0.44]}\end{array}$ & $\begin{array}{r}0.0353 \\
{[0.46]}\end{array}$ & $\begin{array}{r}0.0421 \\
{[0.55]}\end{array}$ & $\begin{array}{r}0.0956 \\
{[1.44]}\end{array}$ & $\begin{array}{r}0.0847 \\
{[1.34]}\end{array}$ & $\begin{array}{r}0.0837 \\
{[1.33]}\end{array}$ & $\begin{array}{r}0.0908 \\
{[1.33]}\end{array}$ \\
\hline Debt Ratio & $\begin{array}{r}-0.0006 \\
{[0.63]}\end{array}$ & $\begin{array}{r}-0.0033 \\
-[0.49]\end{array}$ & $\begin{array}{l}-0.0005 \\
-[0.55]\end{array}$ & $\begin{array}{r}-0.0014 \\
-[0.38]\end{array}$ & $\begin{array}{r}-1 \mathrm{E}-04 \\
{[0.46]}\end{array}$ & $\begin{array}{r}-0.0014 \\
-[0.56]\end{array}$ & $\begin{array}{l}-0.0056 \\
-[0.64]\end{array}$ & $\begin{array}{l}-0.0065 \\
-[0.61]\end{array}$ \\
\hline Ln(offer price) & $\begin{array}{l}-0.0021 \\
-[0.02]\end{array}$ & $\begin{array}{r}0.0016 \\
-[0.01]\end{array}$ & $\begin{array}{l}-0.0069 \\
-[0.02]\end{array}$ & $\begin{array}{r}-0.0055 \\
{[0.00]}\end{array}$ & $\begin{array}{l}-0.0273 \\
-[1.07]\end{array}$ & $\begin{array}{l}-0.025 \\
-[1.11]\end{array}$ & $\begin{array}{l}-0.031 \\
-[1.10]\end{array}$ & $\begin{array}{l}-0.0327 \\
-[1.05]\end{array}$ \\
\hline $\begin{array}{l}\text { Venture Backed } \\
\text { (dummy) }\end{array}$ & $\begin{array}{l}-0.1121^{* *} \\
-[2.29]\end{array}$ & $\begin{array}{l}-0.0937^{* *} \\
-[2.31]\end{array}$ & $\begin{array}{l}-0.0994^{* *} \\
-[2.30]\end{array}$ & $\begin{array}{l}-0.1213^{* *} \\
-[2.15]\end{array}$ & $\begin{array}{l}-0.1113^{* *} \\
-[2.28]\end{array}$ & $\begin{array}{l}-0.1356^{* *} \\
-[2.41]\end{array}$ & $\begin{array}{l}-0.1153^{* *} \\
-[2.52]\end{array}$ & $\begin{array}{l}-0.1307^{* *} \\
-[2.50]\end{array}$ \\
\hline KOSPI (dummy) & $\begin{array}{l}0.2171^{* *} \\
{[2.55]}\end{array}$ & $\begin{array}{l}0.1673^{* * *} \\
{[2.80]}\end{array}$ & $\begin{array}{l}0.1186^{* *} \\
{[2.26]}\end{array}$ & $\begin{array}{l}0.1152^{* *} \\
{[2.23]}\end{array}$ & $\begin{array}{l}0.2995^{* * *} \\
{[2.85]}\end{array}$ & $\begin{array}{l}0.2167^{* * *} \\
{[2.65]}\end{array}$ & $\begin{array}{l}0.1847^{* * *} \\
{[2.67]}\end{array}$ & $\begin{array}{l}0.1732^{* * *} \\
{[2.64]}\end{array}$ \\
\hline Market returns & $\begin{array}{c}-0.0189^{*} \\
-[1.68]\end{array}$ & $\begin{array}{l}-0.0267^{*} \\
-[1.73]\end{array}$ & $\begin{array}{c}-0.0239^{*} \\
-[1.71]\end{array}$ & $\begin{array}{l}-0.0221^{*} \\
-[1.73]\end{array}$ & $\begin{array}{c}-0.0205^{*} \\
-[1.80]\end{array}$ & $\begin{array}{c}-0.0242^{*} \\
-[1.86]\end{array}$ & $\begin{array}{l}-0.0207^{*} \\
-[1.90]\end{array}$ & $\begin{array}{l}-0.0218^{*} \\
-[1.88]\end{array}$ \\
\hline Intercept & $\begin{array}{l}1.3152^{* * * *} \\
{[5.90]}\end{array}$ & $\begin{array}{l}1.3472^{* * *} \\
{[5.95]}\end{array}$ & $\begin{array}{l}1.366^{* * *} \\
{[6.01]}\end{array}$ & $\begin{array}{l}1.353^{* * *} \\
{[5.93]}\end{array}$ & $\begin{array}{l}1.5631^{* * *} \\
{[5.13]}\end{array}$ & $\begin{array}{l}1.6252^{* * *} \\
{[5.29]}\end{array}$ & $\begin{array}{l}1.6312^{* * *} \\
{[5.28]}\end{array}$ & $\begin{array}{c}1.6282^{* * * *} \\
{[5.32]} \\
\end{array}$ \\
\hline No. of obs & 740 & 740 & 740 & 740 & 707 & 707 & 707 & 707 \\
\hline $\mathrm{F}$ tests & 15.21 & 14.60 & 14.35 & 13.67 & 11.24 & 9.79 & 10.66 & 9.82 \\
\hline $\mathrm{R}^{2}$ & 0.10 & 0.10 & 0.10 & 0.10 & 0.07 & 0.07 & 0.07 & 0.07 \\
\hline
\end{tabular}

<표 4>는 IPO 3개월 전 업종 내 상장기업들에 대한 애널리스트 투자의견과 IPO 저가평가율 간 관계를 분석한 결과이다. 상장기업 수 대비 투자의견 제시비율인 \% Anal Coverage은 저가발행률에 유의한 음(-)의 영향을 미치는 것으로 나타났다. 애널리스트 커버리지는 해당 업종에 대한 시장의 관심을 반영하며, 업종 내 기업들에 대한 정보불균형을 완화하는 역할을 하기 때문으로 해석할 수 있다. 투자의견 상향비율(\% Rating Up)의 회귀계수 또한 유의한 음(-)의 값을 보였다. 즉 시장에서 해당 업종에 대한 관심이 많고, 업종 내 기업들에 대한 호의적 평가가 많을수록 신규 상장기업의 공모가가 높아지고 저가평가율이 작아진다. 이는 기존 상장기업들에 대한 긍정적 평가가 IPO 기업의 주가에도 긍정적 영향을 미친다는 전염효과 가설을 지지한다. 한편 기존 상장기업에 대한 투자의견 하향(\% Rating Down)은 유의한 영향을 미치지 못하는 것으로 나타났다. 투자의견 하향은 일견 업종 내 경쟁기업들에 대한 부정적 평가를 반영하는 것이나 다른 한편으로는 해당 업종에 대한 정보불균형을 완화시키는 효과가 있기 때문인 것으로 해석될 수 있다. 
〈표 4〉애널리스트 투자의견 및 순이익 예측 변수들의 단순통계량

아래 표는 애널리스트 투자의견 및 순이익 예측 관련 단순통계량을 보여준다. \% Anal Coverage, \% Rating Up, \% Rating Down, \% Rating Net, \% Earning Coverage, \% Earning Up, \% Earning Down and \% Earning Net 등 변수들은 3.2절에서 정의되었다.

\begin{tabular}{lcrrrr}
\hline & Mean $(\%)$ & $\mathrm{p} 25(\%)$ & $\mathrm{p} 50(\%)$ & $\mathrm{p} 75(\%)$ & $\mathrm{p} 95(\%)$ \\
\hline \% Anal Coverage & 87.20 & 23.81 & 41.07 & 85.25 & 350.70 \\
\% Rating Up & 1.59 & 0 & 0 & 2.00 & 7.04 \\
\% Rating Down & 1.23 & 0 & 0 & 1.30 & 6.52 \\
\% Rating Net & 0.37 & 1.00 & 0 & 0 & 2.82 \\
\% Earning Coverage & 84.87 & 23.29 & 40.18 & 83.61 & 337.04 \\
\% Earning Up & 11.89 & 4.88 & 4.65 & 12.68 & 53.45 \\
\% Earning Down & 10.06 & 1.30 & 4.65 & 11.48 & 40.98 \\
\% Earning Net & 1.83 & 3.57 & 0 & 5 & 30.99 \\
\hline
\end{tabular}

통제변수 중 공모규모(Ln(proceeds))가 크거나 연혁(Firm Age)이 많은 기업일수록 저가 발행률은 낮은 것으로 나타났는데, 이러한 기업들의 정보가 공모전 시장에 더 많이 노출되므로 불확실성이 완화된다는 기존 연구의 결과와 일치한다(Habib and Ljungqvist, 1998; Ljungqvist, 2007). 벤쳐캐피탈이 투자한 IPO(Venture Backed)도 저가발행률이 유의하게 낮게 나타나는데, 이는 벤쳐캐피탈이 IPO 기업 가치에 대한 인증(certification)과 정보전달 기능을 수행하기 때문이다(Megginson and Weiss, 1991; Belghitar and Dixon, 2012; Song and Jeon, 2019).5) 한편 주관사의 명성(Underwriter Prestige)의 영향은 통계적으로 유의하지 않아 국내 시장에서 명성이 높은 주관사가 더욱 충실한 인증서비스를 제공한다는 가설(Carter and Manaster, 1990)이 지지되지 않았다.

<표 5>는 IPO 전 3개월 동안 업종 내 상장기업들에 대한 애널리스트 이익예측과 IPO 저가 평가율 간 관계를 분석한 결과이다. 먼저 \% Earning Coverage의 회귀계수는 유의한 음(-)의 값을 갖는 것으로 나타나 기존 상장기업들에 대한 이익예측 보고가 많을수록 업종 내 기업들의 미래 이익에 대한 불확실성이 완화되며 IPO 주가에 긍정적 영향을 미쳤다고 볼 수 있다. 그러나 기존 상장기업들에 대한 미래 이익 예측치가 상항(\%Earning UP)할 경우 IPO의 저가발행률은 유의적으로 높아진다. IPO 기업의 관점에서 기존 상장기업들은 업종 내 경쟁대상이므로 이들의 미래이익 예측치 상승은 신규 상장 후 성장에 부정적 영향을 미칠 것이기 때문이다. 반면 경쟁기업에 대한 이익 예측치 하향은 $\mathrm{IPO}$ 기업의 경쟁적 지위 상승에 긍정적 영향을 미칠 수 있다. 이에 따라 \%Earning Down의 회귀계수는 통계적으로 유의한 음의 값을 갖는 것으로 나타났다. 한편, 이익 예측치 상향 비율에서 하향 비율을 차감한 순 상향비율(\% Earning Net)의 회귀계수 역시 정(+)의 값을 갖는 것으로 나타났다. 요컨대 <표 5>에서 기존 상장기업들에 대한 애널리스트의 긍정적 투자의견이 IPO 주가에 긍정적 영향을 미친다는 전염효과가 지지된 반면, <표 5>에서는 기존 상장기업들에 대한 긍정적 예측이익이 IPO 주가가 부정적 영향을

5) 반면에 Lee and Wahal(2004)은 내생성 통제 후 실증분석을 통해 벤쳐캐피탈이 오히려 IPO 초기 수익률을 높인다고 보고하였고 이는 벤쳐캐피탈의 과시효과(grandstanding) 때문이라고 하였다. 
Spillover Effects of Analyst Coverage on IPO Firms

미친다는 경쟁효과가 지지되었다. 한편, 통제변수의 회귀계수는 <표 $4>$ 와 유사하게 추정 되었다.

\section{〈표 5〉경쟁기업들에 대한 이익예측과 IPO 저가평가율}

아래 표는 IPO 전 3개월 동안 업종 내 상장기업들에 대한 애널리스트 이익예측과 IPO 저가평가율 간 관계를 분석한 결과이다. 종속변수는 IPO 첫날수익률 및 상장 후 5 일간 수익률이다. 모든 변수들은 3.2절에 정의되었다. 꺽쇠괄호 안의 숫자는 robust standard errors로 계산된 t값 이다. 업종과 연도 더미변수들은 회귀식에 포함되었지만 회귀계수는 보고하지 않았다. *, ${ }^{* *},{ }^{* * *}$ 는 각각 $10 \%, 5 \%, 1 \%$ 에서 통계적으로 유의함을 나타낸다.

\begin{tabular}{|c|c|c|c|c|c|c|c|c|}
\hline Dependent Var: & & First-day & Returns & & & 5-day $\mathrm{F}$ & eturns & \\
\hline \% Earning Coverage & $\begin{array}{l}-0.042^{* *} \\
-[2.01]\end{array}$ & & & & $\begin{array}{c}-0.0679^{* *} \\
-[2.14]\end{array}$ & & & \\
\hline$\%$ Earning Up & & $\begin{array}{l}0.076^{*} \\
{[1.73]}\end{array}$ & & & & $\begin{array}{c}0.1152^{*} \\
{[1.91]}\end{array}$ & & \\
\hline \% Earning Down & & & $\begin{array}{l}-0.3713^{* *} \\
-[2.11]\end{array}$ & & & & $\begin{array}{l}-0.379^{* *} \\
-[2.27]\end{array}$ & \\
\hline \% Earning Net & & & & $\begin{array}{r}0.1108 \\
{[1.26]}\end{array}$ & & & & $\begin{array}{l}0.101^{*} \\
{[1.91]}\end{array}$ \\
\hline Ln(proceeds) & $\begin{array}{l}-0.0994^{* * *} \\
-[5.76]\end{array}$ & $\begin{array}{l}-0.1073^{* * *} \\
-[6.04]\end{array}$ & $\begin{array}{l}-0.11^{* * *} \\
-[6.19]\end{array}$ & $\begin{array}{l}-0.1145^{* * *} \\
-[6.09]\end{array}$ & $\begin{array}{c}-0.0865^{* * *} \\
-[3.80]\end{array}$ & $\begin{array}{l}-0.1024^{* * *} \\
-[4.18]\end{array}$ & $\begin{array}{l}-0.0984^{* * *} \\
-[4.02]\end{array}$ & $\begin{array}{l}-0.0991^{* * *} \\
-[4.19]\end{array}$ \\
\hline Age & $\begin{array}{l}-0.0215^{* *} \\
-[2.21]\end{array}$ & $\begin{array}{c}-0.0191^{*} \\
-[1.91]\end{array}$ & $\begin{array}{c}-0.0276^{*} \\
-[1.81]\end{array}$ & $\begin{array}{l}-0.0236^{* *} \\
-[2.22]\end{array}$ & $\begin{array}{l}-0.0522^{*} \\
-[1.87]\end{array}$ & $\begin{array}{l}-0.045^{*} \\
-[1.97]\end{array}$ & $\begin{array}{c}-0.0581^{*} \\
-[1.77]\end{array}$ & $\begin{array}{c}-0.0534^{*} \\
-[1.93]\end{array}$ \\
\hline Underwriter Prestige & $\begin{array}{l}-0.0168 \\
-[0.92]\end{array}$ & $\begin{array}{l}-0.0563 \\
-[0.73]\end{array}$ & $\begin{array}{l}-0.0427 \\
-[1.09]\end{array}$ & $\begin{array}{l}-0.047 \\
-[1.22]\end{array}$ & $\begin{array}{l}0.0014 \\
-[1.54]\end{array}$ & $\begin{array}{l}-0.0496 \\
-[1.20]\end{array}$ & $\begin{array}{l}-0.0426 \\
-[1.35]\end{array}$ & $\begin{array}{l}-0.0597^{*} \\
-[1.75]\end{array}$ \\
\hline $\mathrm{ROA}$ & $\begin{array}{r}0.0395 \\
{[0.59]}\end{array}$ & $\begin{array}{r}0.0416 \\
{[0.52]}\end{array}$ & $\begin{array}{r}0.0285 \\
{[0.42]}\end{array}$ & $\begin{array}{r}0.0276 \\
{[0.43]}\end{array}$ & $\begin{array}{r}0.0923 \\
{[1.43]}\end{array}$ & $\begin{array}{c}0.0852 \\
{[1.44]}\end{array}$ & $\begin{array}{r}0.0727 \\
{[1.18]}\end{array}$ & $\begin{array}{r}0.0757 \\
{[1.19]}\end{array}$ \\
\hline Debt Ratio & $\begin{array}{r}0.0007 \\
{[0.65]}\end{array}$ & $\begin{array}{l}-0.0001 \\
-[0.18]\end{array}$ & $\begin{array}{l}-0.0005 \\
-[0.59]\end{array}$ & $\begin{array}{l}-0.0024 \\
-[0.89]\end{array}$ & $\begin{array}{r}0.0034 \\
{[0.56]}\end{array}$ & $\begin{array}{r}-0.0035 \\
-[0.20]\end{array}$ & $\begin{array}{l}-0.0016 \\
-[0.72]\end{array}$ & $\begin{array}{l}-0.011 \\
-[0.89]\end{array}$ \\
\hline Ln(offer price) & $\begin{array}{l}-0.0052 \\
-[0.08]\end{array}$ & $\begin{array}{l}-0.0036 \\
-[0.02]\end{array}$ & $\begin{array}{l}-0.0066 \\
-[0.01]\end{array}$ & $\begin{array}{r}-0.0021 \\
{[0.08]}\end{array}$ & $\begin{array}{l}-0.0321 \\
-[1.11]\end{array}$ & $\begin{array}{l}-0.0309 \\
-[1.05]\end{array}$ & $\begin{array}{l}-0.0331 \\
-[1.11]\end{array}$ & $\begin{array}{l}-0.0294 \\
-[1.13]\end{array}$ \\
\hline $\begin{array}{l}\text { Venture Backed } \\
\text { (dummy) }\end{array}$ & $\begin{array}{l}-0.1131^{* *} \\
-[2.12]\end{array}$ & $\begin{array}{l}-0.0859^{* *} \\
-[2.33]\end{array}$ & $\begin{array}{l}-0.105^{* *} \\
-[2.21]\end{array}$ & $\begin{array}{l}-0.1232^{* *} \\
-[2.25]\end{array}$ & $\begin{array}{l}-0.094^{* *} \\
-[2.42]\end{array}$ & $\begin{array}{l}-0.1256^{* *} \\
-[2.34]\end{array}$ & $\begin{array}{l}-0.1157^{* *} \\
-[2.14]\end{array}$ & $\begin{array}{l}-0.114^{* *} \\
-[2.29]\end{array}$ \\
\hline KOSPI (dummy) & $\begin{array}{c}0.2180^{* *} \\
{[2.53]}\end{array}$ & $\begin{array}{c}0.1397^{*} \\
{[1.97]}\end{array}$ & $\begin{array}{l}0.2097^{* * *} \\
{[3.31]}\end{array}$ & $\begin{array}{l}0.1114^{* *} \\
{[2.14]}\end{array}$ & $\begin{array}{l}0.3065^{* * *} \\
{[2.98]}\end{array}$ & $\begin{array}{c}0.2156^{* *} \\
{[2.35]}\end{array}$ & $\begin{array}{l}0.2705^{* * *} \\
{[3.69]}\end{array}$ & $\begin{array}{l}0.1732^{* * *} \\
{[2.65]}\end{array}$ \\
\hline Market returns & $\begin{array}{c}-0.0252^{*} \\
-[1.71]\end{array}$ & $\begin{array}{c}-0.0255^{*} \\
-[1.75]\end{array}$ & $\begin{array}{c}-0.0239^{*} \\
-[1.69]\end{array}$ & $\begin{array}{c}-0.0266^{*} \\
-[1.73]\end{array}$ & $\begin{array}{c}-0.0235^{*} \\
-[1.81]\end{array}$ & $\begin{array}{c}-0.0254^{*} \\
-[1.84]\end{array}$ & $\begin{array}{c}-0.0182^{*} \\
-[1.85]\end{array}$ & $\begin{array}{l}-0.0217^{*} \\
-[1.87]\end{array}$ \\
\hline Intercept & $\begin{array}{l}1.3139^{* * *} \\
{[2.99]}\end{array}$ & $\begin{array}{l}1.36^{* * *} \\
{[3.73]}\end{array}$ & $\begin{array}{l}1.3649^{* * *} \\
{[3.64]}\end{array}$ & $\begin{array}{l}1.375^{* * *} \\
{[3.43]}\end{array}$ & $\begin{array}{l}1.555^{* * * *} \\
{[5.19]}\end{array}$ & $\begin{array}{l}1.6144^{* * * *} \\
{[5.30]}\end{array}$ & $\begin{array}{l}1.609^{* * * *} \\
{[5.26]}\end{array}$ & $\begin{array}{l}1.6319^{* * *} \\
{[5.33]}\end{array}$ \\
\hline No. of obs & 740 & 740 & 740 & 740 & 707 & 707 & 707 & 707 \\
\hline $\mathrm{F}$ tests & 15.36 & 14.24 & 12.92 & 12.84 & 11.67 & 9.97 & 9.97 & 9.40 \\
\hline $\mathrm{R}^{2}$ & 0.10 & 0.10 & 0.11 & 0.10 & 0.07 & 0.07 & 0.07 & 0.07 \\
\hline
\end{tabular}

<표 6>은 IPO 기업 및 기존 상장기업들의 업종 내 경쟁적 지위를 고려한, 상장기업에 대한 애널리스트 투자의견이 IPO 저가평가율에 미치는 영향을 분석한 결과이다.6) Panel A에서

6) <표 6> <표 8>에서 통제변수들에 대한 회귀계수 추정결과는 <표 4>, <표 5>와 비슷하므로 보고를 생략하였다. 
Leader IPO는 IPO 기업이 상장 직후 매출액 기준 업종 내 상위 $25 \%$ 일 경우를, Panel B에서는 Follower IPO는 상장 직후 업종 내 상위 $25 \%$ 일 경우를 의미한다. Panel A에서 업종 내 우월적 경쟁지위를 갖게 될 $\mathrm{IPO}$ 는 비슷한 경쟁적 위치에 있는 상장기업들에 대한 투자의견에 더욱 민감하게 반응한다. 매출액 상위 $25 \%$ 기업들에 대한 투자의견 비율(\% Anal Coverage)이 높을수록 그리고 투자의견 상향 비율(\% Rating Up)과 상향비율-하향비율(\% Rating Net)이 높을수록 IPO 저가평가율이 유의하게 감소하였다. 해당 기업들에 대한 투자의견 하향 비율 $(\%$ Rating Down)은 유의한 영향을 미치지 않았다. 추정된 회귀계수들을 <표 $4>$ 와 비교해 보면, 회귀계수의 절대값이 크고 통계적 유의성이 높아 투자의견의 전염효과가 비슷한 경쟁적 지위에 있는 기존 상장기업 표본을 사용할 경우 더욱 강하게 나타난다는 것을 알 수 있다. 한편, 상위 $25 \%$ 에 있지 않은 기존 상장기업들에 대한 투자의견은 저가발행률에 유의한 영향을 미치지 않았다.

〈표 6〉경쟁적 지위를 고려한 애널리스트 투자의견과 IPO 저가평가

아래 표는 IPO 기업과 기존 상장기업의 경쟁적 지위를 고려하여, 애널리스트 추천 변경이 IPO 저가평가에 미치는 영향을 분석한 결과이다. Panel A에서는 매출액 기준 업종 상위 $25 \%$ 에 속하는 Leader IPOs 표본을 사용하였고, Panel B에서는 업종 하위 $25 \%$ 에 속하는 Follower IPOs 표본을 사용하였다. 종속변수는 $\mathrm{IPO}$ 첫날수익률 및 상장 후 5일간 수익률이다. 모든 변수들은 3.2절에 정의되었다. 꺽쇠괄호 안의 숫자는 robust standard errors로 계산된 t값이다. 업종과 연도 더미변수들은 회귀식에 포함되었지만 회귀계수는 보고하지 않았다. *, **, ***는 각각 $10 \%, 5 \%, 1 \%$ 에서 통계적으로 유의함을 나타낸다.

Panel A: Leader IPOs의 저가평가 결정요인

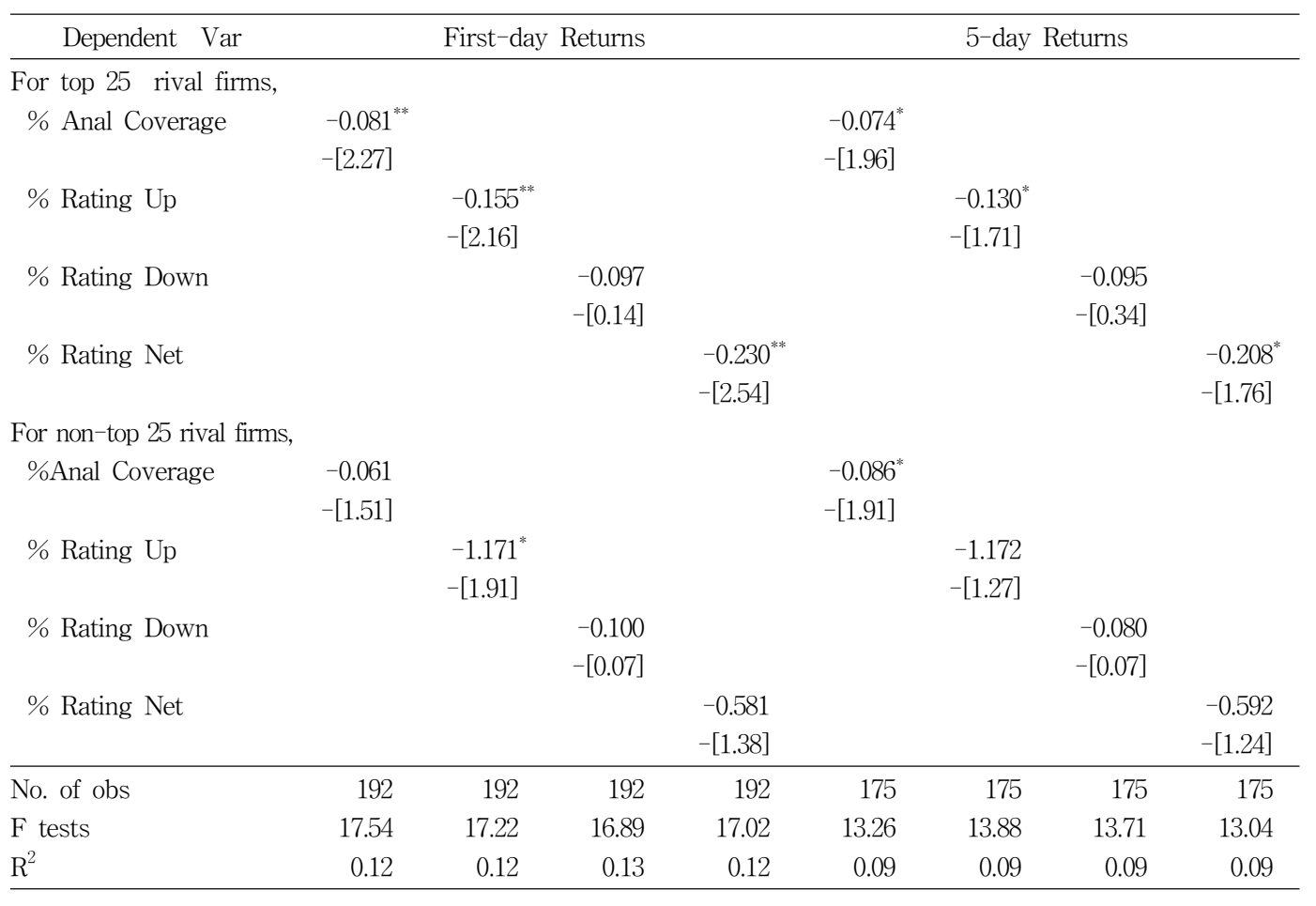


Spillover Effects of Analyst Coverage on IPO Firms

〈표 6〉 경쟁적 지위를 고려한 애널리스트 투자의견과 IPO 저가평가(계속)

Panel B: Follower IPOs의 저가평가 결정요인

\begin{tabular}{|c|c|c|c|c|c|c|c|c|}
\hline \multicolumn{2}{|l|}{ Dependent Var: } & \multicolumn{3}{|c|}{ First-day Returns } & \multicolumn{4}{|c|}{ 5-day Returns } \\
\hline \multicolumn{9}{|c|}{ For bottom 25 rival firms, } \\
\hline$\%$ Anal Coverage & $\begin{array}{l}-0.122^{*} \\
-[1.96]\end{array}$ & & & & $\begin{array}{l}-0.100^{* *} \\
-[2.15]\end{array}$ & & & \\
\hline \% Rating Up & & $\begin{array}{l}-0.144^{* *} \\
-[2.12]\end{array}$ & & & & $\begin{array}{l}-0.121^{* *} \\
-[2.24]\end{array}$ & & \\
\hline \% Rating Down & & & $\begin{array}{l}0.208^{*} \\
{[1.75]}\end{array}$ & & & & $\begin{array}{l}0.195^{*} \\
{[1.70]}\end{array}$ & \\
\hline$\%$ Rating Net & & & & $\begin{array}{l}-0.031 \\
-[0.80]\end{array}$ & & & & $\begin{array}{l}-0.035 \\
-[0.68]\end{array}$ \\
\hline \multicolumn{9}{|c|}{ For non-bottom 25 rival firms, } \\
\hline \%Anal Coverage & $\begin{array}{l}-0.107^{* *} \\
-[2.47]\end{array}$ & & & & $\begin{array}{l}-0.093^{* *} \\
-[2.32]\end{array}$ & & & \\
\hline \% Rating Up & & $\begin{array}{l}-0.099^{*} \\
-[1.90]\end{array}$ & & & & $\begin{array}{l}-0.109^{*} \\
-[1.92]\end{array}$ & & \\
\hline \% Rating Down & & & $\begin{array}{l}-0.036 \\
-[0.92]\end{array}$ & & & & $\begin{array}{l}-0.038 \\
-[1.05]\end{array}$ & \\
\hline$\%$ Rating Net & & & & $\begin{array}{l}-0.059^{*} \\
-[1.86]\end{array}$ & & & & $\begin{array}{l}-0.076^{*} \\
-[1.71]\end{array}$ \\
\hline No. of obs & 145 & 145 & 145 & 145 & 128 & 128 & 128 & 128 \\
\hline $\mathrm{F}$ tests & 20.44 & 21.02 & 20.89 & 19.72 & 15.02 & 15.33 & 16.01 & 15.72 \\
\hline $\mathrm{R}^{2}$ & 0.13 & 0.13 & 0.13 & 0.12 & 0.10 & 0.10 & 0.09 & 0.10 \\
\hline
\end{tabular}

Panel B는 IPO 기업이 업종 내 매출액 기준 하위 $25 \%$ 일 경우 저가발행률을 분석한 결과이다. Panel A의 결과와 동일하게 IPO 기업과 비슷한 경쟁적 지위에 있는 매출액 하위 $25 \%$ 상장기업들에 대한 투자의견 비율(\% Anal Coverage)과 투자의견 상향 비율(\% Rating Up)이 저가발행률과 역의 관계가 있음을 보이고 있다. 더욱이 투자의견 하향 비율(\% Rating Down)이 공모가에 불리하게 작용하여 저가발행률을 높이는 것으로 나타난 점도 전염효과를 지지하고 있다. 또한 Follower IPO의 저가발행률은 자신들 보다 경쟁우위에 있는 매출액 상위 $75 \%$ 인 상장기업들에 대한 투자의견에도 영향을 받는다. Leader $\mathrm{IPO}$ 의 주가는 상위 $25 \%$ 이하 상장기업 들에 대한 투자의견에 영향을 받지 않음을 보여준 Panel A의 결과와는 다르게, 경쟁열위에 있는 IPO의 경우 자신들과 비슷한 경쟁적 지위에 있는 상장기업 뿐만 아니라 경쟁우위에 있는 상장기업들에 대한 투자의견에 영향을 받는다는 것은 흥미로운 결과이다.

<표 7>은 기존 상장기업에 대한 애널리스트 이익예측이 IPO 저가평가율에 미치는 영향에 대하여 IPO 기업 및 상장기업들의 업종 내 경쟁적 지위를 고려하여 분석한 결과이다. Panel A에서 상장 직후 매출액 기준 업종 내 상위 $25 \%$ 에 속하는 Leader $\mathrm{IPO}$ 의 저가발행률은 상장 중인 상위 $25 \%$ 기업들에 대한 이익예측 비율(\% Earning Coverage)이 많을수록 감소한다. 특정 업종에 대하여 애널리스트들의 이익예측 보고가 많다는 것은 해당 업종에 대한 시장의 관심이 높다는 것을 의미하기 때문이다. 또한 <표 5>의 결과와 같이 매출액 상위 $25 \%$ 기업들에 대한 예측이익 상향은 저가평가율을 오히려 높이는 것으로 나타났다. 이는 경쟁자의 미래 예측이익의 상향은 
$\mathrm{IPO}$ 기업의 업종 내 경쟁적 지위에 불리한 영향을 미치기 때문이라고 해석될 수 있으므로 경쟁효과 가설을 지지한다. 한편 하위 $75 \%$ 기업들에 대한 예측이익은 유의한 영향을 미치지 않았다.

Panel B에서 매출액 기준 업종 내 하위 $25 \%$ 인 Follower IPO의 경우도 비슷한 경쟁적 지위에 있는 하위 25\% 상장기업들에 대한 예측이익비율(\% Earning Coverage)과 저가발행률 간 부(-)에 관계가 관찰되었다. Panel $\mathrm{A}$ 와 마찬가지로 예측이익 상향비율(\% Earning Coverage)과 저가발행률 간 정 $(+)$ 의 관계가 나타나 경쟁효과 가설을 지지하였다. 더욱이 예측이익 상향비율과 하향비율의 차이(\% Earning Net) 또한 저가발행률을 유의하게 증가시키는 것으로 나타났다. Follower IPO가 Panel A의 Leader IPO에 대한 결과와 다른 점은 매출액 상위 $75 \%$ 기업들에 대한 예측이익에도 영향을 받는 다는 점이다. 상위 $75 \%$ 기업들에 대한 예측이익 비율과 예측이익 상향비율이 높을수록 저가발행률이 유의하게 낮아지는 것으로 나타났다. 경쟁적 우위에 있는 이들 상위 $75 \%$ 기업들에 대한 예측이익 상향은 IPO 기업의 경쟁적 지위를 위협하기 보다는 해당 업종에 대한 시장의 호감을 반영하여 공모가에 긍정적 영향을 미친다고 해서 될 수 있다.

\section{〈표 7〉 경쟁적 지위를 고려한 애널리스트 이익예측과 IPO 저가평가}

아래 표는 IPO 기업과 기존 상장기업의 경쟁적 지위를 고려하여, 애널리스트 이익예측이 IPO 저가평가에 미치는 영향을 분석한 결과이다. Panel A에서는 매출액 기준 업종 상위 $25 \%$ 에 속하는 Leader IPOs 표본을 사용하였고, Panel B에서는 업종 하위 $25 \%$ 에 속하는 Follower IPOs 표본을 사용하였다. 종속변수는 $\mathrm{IPO}$ 첫날수익률 및 상장 후 5 일간 수익률이다. 모든 변수들은 3.2 절에 정의되었다. 꺽쇠괄호 안의 숫자는 robust standard errors로 계산된 t값 이다. 업종과 연도 더미변수들은 회귀식에 포함되었지만 회귀계수는 보고하지 않았다. ${ }^{*},{ }^{* *},{ }^{* * *}$ 는 각각 $10 \%, 5 \%, 1 \%$ 에서 통계적으로 유의함을 나타낸다.

Panel A: Leader IPOs의 저가평가 결정요인

\begin{tabular}{|c|c|c|c|c|c|c|c|c|}
\hline \multirow{2}{*}{$\begin{array}{l}\text { Dependent Var : } \\
\text { For top } 25 \text { rival firms } \\
0 \text { Farning } \text { Coverage }\end{array}$} & \multicolumn{4}{|c|}{ First-day Returns } & \multicolumn{4}{|c|}{ 5-day Returns } \\
\hline & $\begin{array}{l} \\
-0.126^{* *} \\
-[2.50]\end{array}$ & & & & $\begin{array}{l}-0.100^{* *} \\
-[2.37]\end{array}$ & & & \\
\hline \% Earning Up & & $\begin{array}{l}0.106^{* *} \\
{[2.12]}\end{array}$ & & & & $\begin{array}{c}0.145^{*} \\
{[1.93]}\end{array}$ & & \\
\hline \% Earning Down & & & $\begin{array}{l}-0.535 \\
-[1.01]\end{array}$ & & & & $\begin{array}{l}-0.151 \\
-[0.93]\end{array}$ & \\
\hline$\%$ Earning Net & & & & $\begin{array}{r}0.111 \\
{[1.26]}\end{array}$ & & & & $\begin{array}{l}0.106 \\
{[1.06]}\end{array}$ \\
\hline $\begin{array}{l}\text { For non-top } 25 \text { rival } \\
\% \text { EarningCoverage }\end{array}$ & $\begin{array}{l}\text { firms, } \\
-0.022^{*} \\
-[1.74]\end{array}$ & & & & $\begin{array}{l}-0.043^{*} \\
-[1.88]\end{array}$ & & & \\
\hline \% Earning Up & & $\begin{array}{l}-0.012 \\
-[0.83]\end{array}$ & & & & $\begin{array}{r}0.028 \\
-[0.92]\end{array}$ & & \\
\hline \% Earning Down & & & $\begin{array}{c}0.115 \\
{[0.97]}\end{array}$ & & & & $\begin{array}{r}0.145 \\
{[0.85]}\end{array}$ & \\
\hline$\%$ Earning Net & & & & $\begin{array}{l}-0.013 \\
-[0.70]\end{array}$ & & & & $\begin{array}{l}-0.046 \\
-[0.61]\end{array}$ \\
\hline No. of obs & 192 & 192 & 192 & 192 & 175 & 175 & 175 & 175 \\
\hline $\mathrm{F}$ tests & 14.39 & 13.80 & 14.11 & 14.25 & 12.08 & 10.77 & 10.87 & 10.08 \\
\hline$\underline{\mathrm{R}}^{2}$ & 0.12 & 0.12 & 0.11 & 0.11 & 0.08 & 0.08 & 0.08 & 0.07 \\
\hline
\end{tabular}


Spillover Effects of Analyst Coverage on IPO Firms

〈표 7〉 경쟁적 지위를 고려한 애널리스트 이익예측과 IPO 저가평가(계속)

Panel B: Follower IPOs의 저가평가 결정요인

\begin{tabular}{|c|c|c|c|c|c|c|c|c|}
\hline \multirow{2}{*}{\multicolumn{2}{|c|}{$\frac{\text { Dependent Var : }}{\text { For bottom } 25 \text { rival firms }}$}} & \multicolumn{3}{|c|}{ First-day Returns } & \multicolumn{4}{|c|}{ 5-day Returns } \\
\hline & & & & & & & & \\
\hline \% Earning Coverage & $\begin{array}{l}-0.089^{*} \\
-[1.68]\end{array}$ & & & & $\begin{array}{l}-0.084 \\
-[1.65]\end{array}$ & & & \\
\hline \% Earning Up & & $\begin{array}{l}0.145^{* *} \\
{[2.17]}\end{array}$ & & & & $\begin{array}{l}0.138^{* *} \\
{[2.27]}\end{array}$ & & \\
\hline \% Earning Down & & & $\begin{array}{r}-0.023 \\
{[0.03]}\end{array}$ & & & & $\begin{array}{l}-0.021 \\
-[0.09]\end{array}$ & \\
\hline$\%$ Earning Net & & & & $\begin{array}{l}0.091^{*} \\
{[1.89]}\end{array}$ & & & & $\begin{array}{l}0.078^{*} \\
{[1.72]}\end{array}$ \\
\hline For non-top 25 rival fi & & & & & & & & \\
\hline \% Earning Coverage & $\begin{array}{l}-0.015^{*} \\
-[1.81]\end{array}$ & & & & $\begin{array}{l}-0.024^{* *} \\
-[2.03]\end{array}$ & & & \\
\hline \% Earning Up & & $\begin{array}{l}-0.101^{* *} \\
-[2.08]\end{array}$ & & & & $\begin{array}{l}-0.072^{* *} \\
-[1.98]\end{array}$ & & \\
\hline \% Earning Down & & & $\begin{array}{r}0.096 \\
{[1.11]}\end{array}$ & & & & $\begin{array}{r}0.099 \\
{[0.81]}\end{array}$ & \\
\hline$\%$ Earning Net & & & & $\begin{array}{l}-0.048 \\
-[1.52]\end{array}$ & & & & $\begin{array}{l}-0.022^{*} \\
-[1.68]\end{array}$ \\
\hline No. of obs & 145 & 145 & 145 & 145 & 128 & 128 & 128 & 128 \\
\hline $\mathrm{F}$ tests & 20.44 & 21.02 & 20.89 & 19.72 & 15.02 & 15.33 & 16.01 & 15.72 \\
\hline $\mathrm{R}^{2}$ & 0.13 & 0.13 & 0.13 & 0.12 & 0.10 & 0.10 & 0.09 & 0.10 \\
\hline
\end{tabular}

한편, 애널리스트 보고서의 경쟁효과 및 전염효과를 검증함에 있어서 업종의 상품시장 경쟁도도 주요 고려 변수이다. 경쟁도가 높은 업종은 일반적으로 기업들의 수가 많고 해당 업종 및 기업 관련 정보의 노출이 많다. 반면에 업종 경쟁도가 낮을수록(또는 집중도가 높을수록) 소수 기업의 시장지배력이 높고 신규 기업의 진입이 어려워진다.

<표 8>에서는 업종 별 경쟁도에 따른 경쟁효과 또는 전염효과 가설을 검증하기 위하여 Herfindahl-Hirschman Index $(\mathrm{HHI})$ 를 사용하였다. HHI 값이 클수록 업종 내 집중도가 높으므로 경쟁도는 낮아진다. Panel A에서 $\mathrm{HHI}$ 의 회귀계수는 5-day Returns과 유의한 양 $(+)$ 의 관계를 보였다. 이는 업종 경쟁도가 낮을수록 소수의 기업들의 시장지배력이 강하므로, 업종 내 기업들에 대한 정보비대칭이 높아져 IPO 저가발행률이 높아진다. HHI와 투자의견비율 간 교호변수(\% Earning Coverage*HHI)는 저가발행률을 유의하게 감소시킨다. 집중도가 높은 업종에서 빈번한 애널리스트 투자의견의 제시는 정보비대칭을 완화시키기 때문이다. 또한 \% Anal Up*HHI의 회귀계수도 유의한 부(-)의 값을 갖는다. 이는 경쟁이 강하지 않은 업종에서 기존 상장기업에 대한 투자의견의 상향 정보는 전염효과가 높아 IPO 저가발행을 감소시키기 때문으로 해석된다. Panel B에서 기존 상장기업에 대한 이익예측치 상향비율과 $\mathrm{HHI}$ 간 교호변수(\% Earning $\mathrm{Up} * \mathrm{HHI})$ 의 회귀계수는 통계적으로 유의하지 않아 경쟁효과 가설을 지지하지 않는다. 이러한 결과는 집중도가 높아 업종 경쟁도가 낮을수록 경쟁기업에 대한 이익예측치가 상향되더라도 IPO 기업에는 별다른 영향이 없기 때문이다. Panel C에서 
한국증권학회지 제 50 권 5 호 (2021)

집중도가 높은 업종에서 매출액 기준 상위 $25 \%$ 경쟁기업들의 투자의견 상향은 Leader IPO의 첫날수익률에 유의한 영향을 미친다. Follower IPO 첫날수익률도 하위 $25 \%$ 기업들의 투자의견 상향에 따라 유의하게 줄어든다. 또한 Follower IPO는 업종 내 상위 75\% 기업들의 투자의견 상향에도 유의한 영향을 받는다. 이와 같이 경쟁도가 낮은 업종에서 경쟁기업 투자의견 상향이 미치는 영향은 대체적으로 업종 경쟁도를 고려하지 않은 <표 6>의 결과보다 명확하게 나타난다. Panel D에서 경쟁기업의 이익예측치 변경에 따른 경쟁효과 가설은 업종 경쟁도가 낮을 경우 Leader IPO 경우 유의하게 나타나지 않았다. Follower IPO의 경우 집중도가 높은 시장에서도 업종 내 하위 $25 \%$ 기업의 이익예측치 상승비율과 첫날수익률이 $10 \%$ 유의수준에서 통계적으로 유의한 관계가 있는 것으로 나타나, 집중도가 높은 업종에서도 경쟁효과 가설이 부분적으로 지지된다고 볼 수 있다.

〈표 8〉애널리스트 보고와 산업경쟁도

아래 표는 산업집중도를 고려한 애널리스트 투자의견과 이익예측이 IPO 저가평가에 미치는 영향을 분석한 결과이다. Panel A에서는 애널리스트 투자의견 변경이 IPO 저가평가에 미치는 영향을, Panel B에서는 애널리스트 이익예측이 IPO 저가평가에 미치는 영향을 분석하였다. Panel C와 Panel D는 업종 내 경쟁적 지위를 추가로 고려한 결과이다. 종속변수는 IPO 첫날수익률 및 상장 후 5 일간 수익률이다. $\mathrm{HHI}$ 는 Herfindahl-Hirschman index로 업종 내 모든 기업의 시장점율 제곱의 합이다. 모든 변수들은 3.2절에 정의되었다. 꺽쇠괄호 안의 숫자는 robust standard errors로 계산된 t값 이다. 업종과 연도 더미변수들은 회귀식에 포함되었지만 회귀계수는 보고하지 않았다. *, **, ***는 각각 $10 \%, 5 \%, 1 \%$ 에서 통계적으로 유의함을 나타낸다.

Panel A: 애널리스트 투자의견과 산업경쟁도

\begin{tabular}{|c|c|c|c|c|c|c|c|c|}
\hline \multirow{2}{*}{$\frac{\text { Dependent Var : }}{\% \text { Anal Coverage } * \mathrm{HHI}}$} & \multicolumn{4}{|c|}{ First-day Returns } & \multicolumn{4}{|c|}{ 5-day Returns } \\
\hline & $\begin{array}{l}-0.129^{* *} \\
-[2.22]\end{array}$ & & & & $\begin{array}{l}-0.076^{* *} \\
-[2.18]\end{array}$ & & & \\
\hline \% Rating Up*HHI & & $\begin{array}{l}-2.105^{*} \\
-[1.97]\end{array}$ & & & & $\begin{array}{l}-2.057^{*} \\
-[1.89]\end{array}$ & & \\
\hline \% Rating Down*HHI & & & $\begin{array}{l}-0.146 \\
-[0.44]\end{array}$ & & & & $\begin{array}{l}-0.093 \\
-[0.43]\end{array}$ & \\
\hline \% Rating Net*HHI & & & & $\begin{array}{l}-1.097 \\
-[0.67]\end{array}$ & & & & $\begin{array}{l}-1.037 \\
-[0.67]\end{array}$ \\
\hline $\mathrm{HHI}$ & $\begin{array}{r}0.032 \\
{[1.05]}\end{array}$ & $\begin{array}{r}0.037 \\
{[0.91]}\end{array}$ & $\begin{array}{r}0.042 \\
{[0.88]}\end{array}$ & $\begin{array}{r}0.050 \\
{[0.99]}\end{array}$ & $\begin{array}{l}0.042^{*} \\
{[1.68]}\end{array}$ & $\begin{array}{c}0.053^{*} \\
{[1.72]}\end{array}$ & $\begin{array}{l}0.067^{*} \\
{[1.75]}\end{array}$ & $\begin{array}{l}0.052^{*} \\
{[1.72]}\end{array}$ \\
\hline$\%$ Anal Coverage & $\begin{array}{l}-0.051 \\
-[1.50]\end{array}$ & & & & $\begin{array}{l}-0.060^{*} \\
-[1.80]\end{array}$ & & & \\
\hline \% Rating Up & & $\begin{array}{l}-1.128 \\
-[1.35]\end{array}$ & & & & $\begin{array}{l}-0.853 \\
-[0.35]\end{array}$ & & \\
\hline \% Rating Down & & & $\begin{array}{l}-0.102 \\
-[0.02]\end{array}$ & & & & $\begin{array}{l}-0.133 \\
-[0.22]\end{array}$ & \\
\hline$\%$ Rating Net & & & & $\begin{array}{l}-0.592 \\
-[1.01]\end{array}$ & & & & $\begin{array}{l}-0.272 \\
-[0.12]\end{array}$ \\
\hline No. of obs & 740 & 740 & 740 & 740 & 707 & 707 & 707 & 707 \\
\hline $\mathrm{F}$ tests & 17.88 & 18.24 & 18.02 & 17.90 & 13.55 & 12.02 & 12.20 & 11.98 \\
\hline $\mathrm{R}^{2}$ & 0.12 & 0.12 & 0.11 & 0.11 & 0.08 & 0.08 & 0.09 & 0.08 \\
\hline
\end{tabular}


Spillover Effects of Analyst Coverage on IPO Firms

〈표 8〉애널리스트 보고와 산업경쟁도(계속)

Panel B: 애널리스트 이익예측과 산업경쟁도

\begin{tabular}{|c|c|c|c|c|c|c|c|c|}
\hline Dependent Var: & \multicolumn{4}{|c|}{ First-day Returns } & \multicolumn{4}{|c|}{ 5-day Returns } \\
\hline \% Earning Coverage*HHI & $\begin{array}{l}-0.144^{* *} \\
-[1.99]\end{array}$ & & & & $\begin{array}{l}-0.128^{* *} \\
-[2.04]\end{array}$ & & & \\
\hline$\%$ Earning Up*HHI & & $\begin{array}{l}1.178 \\
{[0.98]}\end{array}$ & & & & $\begin{array}{l}1.145 \\
{[0.87]}\end{array}$ & & \\
\hline \% Earning Down*HHI & & & $\begin{array}{l}-0.588 \\
-[1.04]\end{array}$ & & & & $\begin{array}{l}-0.553 \\
-[1.06]\end{array}$ & \\
\hline$\%$ Earning Net*HHI & & & & $\begin{array}{l}1.058 \\
{[1.57]}\end{array}$ & & & & $\begin{array}{r}1.015 \\
{[1.55]}\end{array}$ \\
\hline $\mathrm{HHI}$ & $\begin{array}{r}0.026 \\
{[0.91]}\end{array}$ & $\begin{array}{r}0.037 \\
{[0.96]}\end{array}$ & $\begin{array}{l}0.026 \\
{[1.05]}\end{array}$ & $\begin{array}{c}0.047 \\
{[0.98]}\end{array}$ & $\begin{array}{l}0.042^{*} \\
{[1.67]}\end{array}$ & $\begin{array}{l}0.055^{*} \\
{[1.74]}\end{array}$ & $\begin{array}{l}0.044^{*} \\
{[1.67]}\end{array}$ & $\begin{array}{c}0.044^{*} \\
{[1.68]}\end{array}$ \\
\hline$\%$ Earning Coverage & $\begin{array}{l}-0.053^{*} \\
-[1.82]\end{array}$ & & & & $\begin{array}{l}-0.059^{*} \\
-[1.82]\end{array}$ & & & \\
\hline \% Earning Up & & $\begin{array}{l}-0.017 \\
-[0.58]\end{array}$ & & & & $\begin{array}{l}-0.111 \\
-[0.51]\end{array}$ & & \\
\hline \% Earning Down & & & $\begin{array}{l}-0.386^{* * *} \\
-[2.92]\end{array}$ & & & & $\begin{array}{l}-0.369^{*} \\
-[1.80]\end{array}$ & \\
\hline$\%$ Earning Net & & & & $\begin{array}{r}0.074 \\
{[0.82]}\end{array}$ & & & & $\begin{array}{r}0.066 \\
{[0.88]}\end{array}$ \\
\hline No. of obs & 740 & 740 & 740 & 740 & 707 & 707 & 707 & 707 \\
\hline $\mathrm{F}$ tests & 16.56 & 15.88 & 16.01 & 16.23 & 10.77 & 11.02 & 10.80 & 10.75 \\
\hline $\mathrm{R}^{2}$ & 0.12 & 0.12 & 0.13 & 0.12 & 0.09 & 0.08 & 0.08 & 0.08 \\
\hline
\end{tabular}

Panel C: 애널리스트 투자의견, 산업경쟁도 그리고 업종 내 경쟁적 지위

\begin{tabular}{|c|c|c|c|c|c|c|c|c|}
\hline \multirow{2}{*}{ Dependent Var } & \multicolumn{4}{|c|}{ First-day Returns of Leader IPOs } & \multicolumn{4}{|c|}{ First-day Returns of Follower IPOs } \\
\hline & \multicolumn{4}{|c|}{ For top 25 rival firms, } & \multicolumn{4}{|c|}{ For bottom 25 rival firms, } \\
\hline \% Anal Coverage*HHI & $\begin{array}{l}-0.297^{* *} \\
-[2.38]\end{array}$ & & & & $\begin{array}{l}-0.330^{*} \\
-[1.96]\end{array}$ & & & \\
\hline \% Rating Up*HHI & & $\begin{array}{l}-0.276^{* *} \\
-[2.22]\end{array}$ & & & & $\begin{array}{l}-0.198^{* *} \\
-[2.27]\end{array}$ & & \\
\hline \% Rating Down*HHI & & & $\begin{array}{l}-0.346 \\
-[0.46]\end{array}$ & & & & $\begin{array}{l}-0.408 \\
-[1.09]\end{array}$ & \\
\hline$\%$ Rating Net*HHI & & & & $\begin{array}{l}-0.500^{*} \\
-[1.72] \\
\end{array}$ & & & & $\begin{array}{l}-0.096 \\
-[0.83] \\
\end{array}$ \\
\hline & & hon-top & rival firr & & For & on-botton & 25 rival & \\
\hline$\%$ Anal Coverage*HHI & $\begin{array}{l}-0.077^{*} \\
-[1.92]\end{array}$ & & & & $\begin{array}{l}-0.186^{* *} \\
-[2.50]\end{array}$ & & & \\
\hline \% Rating Up*HHI & & $\begin{array}{l}-1.214 \\
-[1.07]\end{array}$ & & & & $\begin{array}{l}-0.293^{* *} \\
-[2.10]\end{array}$ & & \\
\hline \% Rating Down*HHI & & & $\begin{array}{l}-0.284 \\
-[0.17]\end{array}$ & & & & $\begin{array}{l}-0.184 \\
-[1.22]\end{array}$ & \\
\hline \% Rating Net*HHI & & & & $\begin{array}{l}-0.590 \\
-[1.45]\end{array}$ & & & & $\begin{array}{l}-0.105^{*} \\
-[1.03]\end{array}$ \\
\hline No. of obs & 192 & 192 & 192 & 192 & 145 & 145 & 145 & 145 \\
\hline $\mathrm{F}$ tests & 18.01 & 18.22 & 17.45 & 17.28 & 19.94 & 20.21 & 20.08 & 19.88 \\
\hline$\underline{\mathrm{R}^{2}}$ & 0.13 & 0.13 & 0.14 & 0.13 & 0.14 & 0.14 & 0.13 & 0.14 \\
\hline
\end{tabular}


한국증권학회지 제 50 권 5 호 (2021)

〈표 8〉애널리스트 보고와 산업경쟁도(계속)

Panel D: 애널리스트 이익예측, 산업경쟁도 그리고 업종 내 경쟁적 지위

\begin{tabular}{|c|c|c|c|c|c|c|c|c|}
\hline \multirow{2}{*}{ Dependent Var : } & \multicolumn{4}{|c|}{ First-day Returns of Leader IPOs } & \multicolumn{4}{|c|}{ First-day Returns of Follower IPOs } \\
\hline & \multicolumn{4}{|c|}{ For top 25 rival firms, } & \multicolumn{4}{|c|}{ For bottom 25 rival firms, } \\
\hline \% Earning Coverage*HHI & $\begin{array}{l}-0.281^{* *} \\
-[2.26]\end{array}$ & & & & $\begin{array}{l}-0.033 \\
-[1.51]\end{array}$ & & & \\
\hline \% Earning Up*HHI & & $\begin{array}{r}1.300 \\
{[1.03]}\end{array}$ & & & & $\begin{array}{l}0.107^{*} \\
{[1.84]}\end{array}$ & & \\
\hline$\%$ Earning Down*HHI & & & $\begin{array}{l}-0.817 \\
-[1.33]\end{array}$ & & & & $\begin{array}{r}0.174 \\
-[0.21]\end{array}$ & \\
\hline \multirow[t]{2}{*}{ \% Earning Net*HHI } & & & & $\begin{array}{l}1.158 \\
{[1.03]}\end{array}$ & & & & $\begin{array}{r}-0.138 \\
{[1.15]}\end{array}$ \\
\hline & For & ton-top & rival fir & & For & n-botton & 25 rival $\mathrm{f}$ & $\mathrm{ms}$ \\
\hline \% Earning Coverage $* \mathrm{HHI}$ & $\begin{array}{l}-0.112^{* *} \\
-[2.26]\end{array}$ & & & & $\begin{array}{l}-0.071 \\
-[1.58]\end{array}$ & & & \\
\hline \% Earning Up*HHI & & $\begin{array}{l}-0.231 \\
-[0.90]\end{array}$ & & & & $\begin{array}{l}-0.074^{*} \\
-[1.75]\end{array}$ & & \\
\hline$\%$ Earning Down*HHI & & & $\begin{array}{l}-0.518 \\
-[1.05]\end{array}$ & & & & $\begin{array}{r}0.055 \\
{[0.86]}\end{array}$ & \\
\hline$\%$ Earning Net*HHI & & & & $\begin{array}{r}0.070 \\
{[0.97]}\end{array}$ & & & & $\begin{array}{r}0.057 \\
-[1.32]\end{array}$ \\
\hline No. of obs & 192 & 192 & 192 & 192 & 145 & 145 & 145 & 145 \\
\hline $\mathrm{F}$ tests & 20.45 & 20.11 & 19.98 & 20.08 & 22.21 & 22.99 & 22.16 & 22.5 \\
\hline $\mathrm{R}^{2}$ & 0.14 & 0.14 & 0.15 & 0.14 & 0.14 & 0.13 & 0.13 & 0.13 \\
\hline
\end{tabular}

\section{5. 결론}

애널리스트 투자정보는 해당 기업뿐만 아니라 동일업종 내 경쟁관게에 있는 기업들에도 영향을 미치는 확산효과를 갖는다. 본 연구에서는 투자정보의 확산효과를 분석하기 위하여 IPO 시장을 대상으로 두 가지 상반된 가설을 검증하였다. 전염효과가설에 의하면 기존 상장기업에 대한 호의적인 투자의견 및 이익예측은 IPO 기업의 주가에도 긍정적인 영향을 미쳐 저가발행률을 낮춘다. 반면에 경쟁효과가설에 의하면 호의적인 투자의견 및 이익예측이 신규 상장기업에게는 불리하게 작용하여 저가발행률을 증가시킨다.

2006년부터 2019년 까지 120건의 KOSPI시장 IPO와 620건의 KOSDAQ시장 IPO를 분석한 결과 기존 상장기업에 대한 투자의견 상향 비율이 높을수록 저가발행률이 유의적으로 낮게 나타나 전염효과 가설을 지지하였다. 반면, 기존 상장기업에 대한 이익예측치의 상향 비율이 높을수록 저가평가율이 높게 나타났는데, 이는 경쟁기업들의 이익 성장이 신규 상장기업의 업종 내 경쟁력에 부정적인 영향을 미치기 때문이며, 경쟁효과 가설을 지지하는 결과이다. 이와 같이 애널리스트의 투자의견과 이익예측은 신규 상장기업에 이질적인 영향을 미치는 것으로 나타났다. 이와 같이 애널리스트의 투자의견과 이익예측은 신규 상장기업에 이질적인 영향을 미치는 것으로 나타났다. 이익예측은 해당 기업 자체의 미래성과에 대한 분석결과이므로 경쟁기업 에게는 부정적 영향을 미치게 된다. 반면에, 투자의견 변경은 기업자체의 미래성과 뿐만 아니라 


\section{Spillover Effects of Analyst Coverage on IPO Firms}

업종의 미래 성장성에 대한 평가가 개입되기 때문에 업종 내 경쟁기업 전체적으로 긍정적 효과를 미칠 수 있다. 또한, 업종 내 매출액 기준 상위 $25 \%$ 에 속하는 IPO 기업의 경우 자신과 비슷한 경쟁적 지위에 있는 기존 상장기업들에 대한 애널리스트 투자정보에만 유의한 영향을 받으나, 매출액 기준 하위 $25 \%$ 에 속하는 IPO 기업은 동 그룹 내 기존 상장기업들 뿐만 아니라 상대적으로 경쟁적 지위가 우월한 상위 $75 \%$ 기업들에 대한 투자정보에 유의한 영향을 받는 것으로 나타났다. 마지막으로, 경쟁도가 낮은 업종에서는 애널리스트 투자의견의 전염효과는 유의하게 나타나지만, 이익예측의 경쟁효과는 유의하게 나타나지 않았다.

본 연구는 최초로 업종 내 기존 상장기업에 대한 애널리스트 투자정보가 신규 IPO 기업의 공모가에 미치는 영향을 분석하였다는데 의의가 있다. 또한 기존 상장기업에 대한 애널리스트 투자의견 상향은 IPO 기업의 공모가에 긍정적인 영향을 미치는 전염효과가 관찰된 반면, 기존 상장기업에 대한 이익예측치 상향은 $\mathrm{IPO}$ 기업의 업종 내 경쟁적 지위에 부정적인 영향을 미치는 경쟁효과가 있음을 보고하였다. 즉, 애널리스트 투자정보 중 투자의견과 이익예측치가 경쟁기업에 이질적인 영향을 미친다는 결과도 시사점이 크다고 할 수 있다. 마지막으로 경쟁효과 또는 전염효과는 기업의 업종 내 경쟁적 지위에 따라 또는 업종 경쟁도에 따라 다르게 나타남을 보였다는 점도 주목할 부분이다. 


\section{References}

Asquith, P., M. Mikhail, and A. S. Au, 2005, Information Content of Equity Analyst Reports, Journal of Financial Economics, Vol. 75 (2), pp. 245-282.

Belghitar, Y., and R. Dixon, 2012, Do Venture Capitalists Reduce Underpricing and Underperformance of IPOs? Applied Financial Economics, Vol. 22, pp. 33-44.

Byun, J. H., and S. S. Cho, 2011, IPO Lock-ups and Underpricing, , Korean Journal of Financial Studies, Vol. 40, pp. 405-429.

Carter, R. B., and S. Manaster, 1990, Initial Public Offerings and Underwriter Reputation, Journal of Finance, Vol. 45, pp. 1045-1067.

Chen, S. S., K. W. Ho, and K. H. Ik, 2005, The Wealth Effect of New Product Indtroductions on Industry Rivals, Journal of Business, Vol. 78, pp. 969-996.

Ferrisa, P. S., N. Jayaramanb, and A. Makhija, 1997, The Response of Competitors to Announcements of Bankruptcy: An Empirical Examination of Contagion and Competitive Effects, Journal of Corporate Finance, Vol. 3, pp. 367-395.

Ha, J. S., D. Kim, and Y. Lee, 2019, Investor Attention and Market Reaction to Analysts' Recommendation Revisions: Evidence from Korean Data, Financial Planning Review, Vol. 12 (2), pp. 61-77.

Habib, M. A., and A. Ljungqvist, 1998, Underpricing and IPO proceeds: A Note, Economics Letters, Vol. 61, pp. 381-383.

Hameed, A., R. Morck, J. Shen, and B. Yeung, 2015, Information, Analysts, and Stock Return Comovement, The Review of Financial Studies, Vol. 28 (11), pp. 3153-3187.

Hetzel, M. G., Z. Li, M. S. Officer, and K. J. Rodgers, 2008, Inter-firm Linkages and the Wealth Effects of Financial Distress along the Supply Chain, Journal of Financial Economics, Vol. 87, pp. 374-387.

Hirshleifer, D., and S.H. Teoh, 2003, Limited Attention, Information Disclosure, and Financial Reporting, Journal of Accounting and Economics, Vol. 36, pp. 337-386.

Hsu, H. C., A. V. Reed, and J. Rocholl, 2010, The New Game in Town: Competitive Effects of IPOs, Journal of Finance, Vol. 82, pp. 495-512.

Israelsen, R. D., 2016. Does Common Analyst Coverage Explain Excess Comovement? Journal of Financial and Quantitative Analysis, Vol. 51 (4), pp. 1193-1229.

Jegadeesh, N., W. Kim, S. D. Krische, and C. Lee, 2004, Analyzing the Analysts: When Do Recommendations Add Value?, The Journal of Finance, Vol. 59 (3), pp. 1083-1124. Kang, S. K., J. Kim, and C. Lim, 2007, Information Asymmetry and Added Value of Analyst Recommendations, Asian Review of Financial Research, Vol. 20 (3), pp. 1-34. 
Spillover Effects of Analyst Coverage on IPO Firms

Kasznik, R., and M. F. McNichols, 2002, Does Meeting Earnings Expectations Matter? Evidence from Analyst Forecast Revisions and Share Prices, Journal of Accounting Research, Vol. 40, pp. $727-759$.

Kim, K. S., and J. W. Park, 2012, Informativeness of Analyst Report and Information Asymmetry among Investor Types, Korean Journal of Financial Studies, Vol. 41, pp. 547-588.

Lang, H. P., and R. M. Stultz, 1992, Contagion and Competitive Intra-industry Effects of Bankruptcy Announcements: An Empirical Analysis, Journal of Financial Economics, Vol. 32, pp. 45-60.

Lee, P. M., and S. Wahal, 2004, Grandstadning, Certification and the Underpricing of Venture Capital Backed IPOs, Journal of Financial Economics, Vol. 73, pp. 375-407.

Li, Y., Q. Sun, and S. Tian, 2018, The Impact of IPO Approval on the Price of Existing Stocks: Evidence from China, Journal of Corporate Finance, Vol. 50, pp. 109-127.

Lim, B. K., P. S. Yoon, and S. H. Park, 2016, Analyst Informativeness and Investors' Trading Behavior: Focus on IPOs, Korean Journal of Financial Studies, Vol. 45, pp. 971-999.

Ljungqvist, A., 2007, IPO underpricing, Handbook of Corporate Finance: Empirical Corporate Finance, Vol. 1.

Megginson, W., and K. A. Weiss, 1991, Venture Capitalist Certification in Initial Public Offerings, Journal of Finance, Vol. 46, pp. 879-903.

Miller, J, 2005, Effects of Preannouncements on Analyst and Stock Price Reactions to Earnings News, Review of Quantitative Finance and Accounting, Vol. 24, pp. 251-275.

Song, C. S., and J. Q. Jeon, 2019, Effect of IPO Underpricing on Seasoned Offerings, Korean Journal of Financial Studies, Vol. 48 (5), pp. 589-616.

Song, M. H., and R. A. Walkling, 2000, Abnormal Returns to Rivals of Acquisition Targets: A Test of the "Acquisition Probability Hypothesis", Journal of Financial Economics, Vol. 55 (2), pp. 143-171. 